Original Investigation | Hematology

\title{
Risk of Infection Associated With Administration of Intravenous Iron A Systematic Review and Meta-analysis
}

Akshay A. Shah, MSc; Killian Donovan, BM, BCh; Claire Seeley, MBBS; Edward A. Dickson, BMBS; Antony J. R. Palmer, DPhil; Carolyn Doree, PhD; Susan Brunskill, MSc; Jack Reid, MBBS; Austin G. Acheson, MD; Anita Sugavanam, MBBS; Edward Litton, PhD; Simon J. Stanworth, DPhil

\begin{abstract}
IMPORTANCE Intravenous iron is recommended by many clinical guidelines based largely on its effectiveness in reducing anemia. However, the association with important safety outcomes, such as infection, remains uncertain.
\end{abstract}

OBJECTIVE To examine the risk of infection associated with intravenous iron compared with oral iron or no iron.

DATA SOURCES Medline, Embase, and Cochrane Central Register of Controlled Trials (CENTRAL) were searched for randomized clinical trials (RCTs) from 1966 to January 31, 2021. Ongoing trials were sought from ClinicalTrials.gov, CENTRAL, and the World Health Organization International Clinical Trials Search Registry Platform.

STUDY SELECTION Pairs of reviewers identified RCTs that compared intravenous iron with oral iron or no iron across all patient populations, excluding healthy volunteers. Nonrandomized studies published since January 1, 2007, were also included. A total of 312 full-text articles were assessed for eligibility.

DATA EXTRACTION AND SYNTHESIS Data extraction and risk of bias assessments were performed according to the Preferred Reporting Items of Systematic Reviews and Meta-analyses (PRISMA) and Cochrane recommendations, and the quality of evidence was assessed using the GRADE (Grades of Recommendation, Assessment, Development, and Evaluation) approach. Two reviewers extracted data independently. A random-effects model was used to synthesize data from RCTs. A narrative synthesis was performed to characterize the reporting of infection.

MAIN OUTCOMES AND MEASURES The primary outcome was risk of infection. Secondary outcomes included mortality, hospital length of stay, and changes in hemoglobin and red blood cell transfusion requirements. Measures of association were reported as risk ratios (RRs) or mean differences.

RESULTS A total of 154 RCTs (32 920 participants) were included in the main analysis. Intravenous iron was associated with an increased risk of infection when compared with oral iron or no iron (RR, 1.17; $95 \% \mathrm{Cl}, 1.04-1.31 ; I^{2}=37 \%$; moderate certainty of evidence). Intravenous iron also was associated with an increase in hemoglobin (mean difference, $0.57 \mathrm{~g} / \mathrm{dL} ; 95 \% \mathrm{Cl}, 0.50-0.64 \mathrm{~g} / \mathrm{dL}$; $P^{2}=94 \%$ ) and a reduction in the risk of requiring a red blood cell transfusion (RR, $0.93 ; 95 \% \mathrm{Cl}, 0.76$ $0.89 ; I^{2}=15 \%$ ) when compared with oral iron or no iron. There was no evidence of an effect on mortality or hospital length of stay.

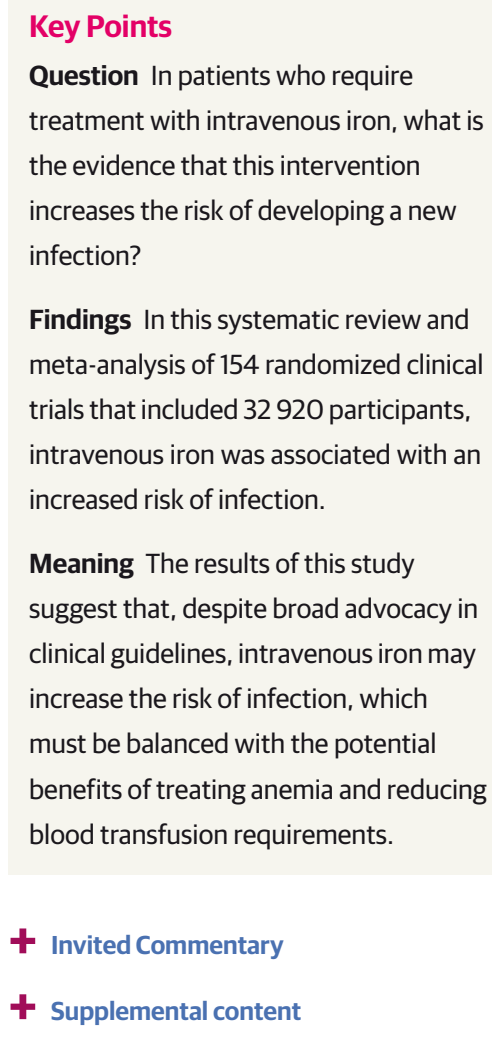

+ Invited Commentary

+ Supplemental content

Author affiliations and article information are listed at the end of this article.

Open Access. This is an open access article distributed under the terms of the CC-BY License. 
Abstract (continued)

CONCLUSIONS AND RELEVANCE In this large systematic review and meta-analysis, intravenous iron was associated with an increased risk of infection. Well-designed studies, using standardized definitions of infection, are required to understand the balance between this risk and the potential benefits.

JAMA Network Open. 2021;4(11):e2133935. doi:10.1001/jamanetworkopen.2021.33935

\section{Introduction}

Intravenous iron is recommended by clinical practice guidelines for the treatment of anemia associated with a range of common conditions, including chronic kidney disease (CKD), heart failure, and inflammatory bowel disease (IBD). During the past decade, its use has expanded to other clinical settings where rapid replenishment of iron stores is required or where oral iron may not be absorbed (eg, chronic inflammation, surgery, and obstetrics) ${ }^{1-7}$ This expansion may, in part, be driven by newer preparations that are reported to be safer with regard to risks such as anaphylaxis when compared with older dextran-based formations, ${ }^{8}$ ease of administration, and increased adoption of patient blood management programs.

Iron is required for host immunity and pathogen replication, and in health, iron is tightly regulated by the peptide hormone hepcidin..$^{9-11}$ Inflammation triggers a process of withholding free iron from invading pathogens, termed nutritional immunity. ${ }^{11,12}$ Intravenous iron increases the levels of circulating non-transferrin-bound iron, which may be detrimental to the host by promoting pathogen growth ${ }^{13}$ and predisposes patients to infection. Recent data suggest that the use of intravenous iron is increasing. ${ }^{14-16}$ Therefore, there is an unmet need to examine whether there is an association between intravenous iron and infection and, if so, whether this association increases morbidity and mortality. ${ }^{17-20}$

Previous systematic reviews ${ }^{21,22}$ have demonstrated the efficacy of intravenous iron for treating anemia and reducing allogeneic red blood cell (RBC) transfusions, but safety data on the risk of infection are conflicting. A recent trial ${ }^{23}$ also questioned the benefit of intravenous iron in patients undergoing major surgery. A systematic review ${ }^{24}$ of 35 international guidelines on the use of intravenous iron across multiple indications found that approximately $60 \%$ of the guidelines have not been updated in more than 5 years and consequently do not reflect the current evidence on the safety and efficacy of intravenous iron. Therefore, we aimed to evaluate the safety and efficacy of intravenous iron by updating a previous systematic review ${ }^{24}$ and focusing primarily on the risk of infection.

\section{Methods}

This report was prepared according to the Preferred Reporting Items for Systematic Reviews and Meta-analyses (PRISMA) reporting guideline. The study protocol was registered with PROSPERO (CRD42018096023) and has been published previously. ${ }^{25}$

\section{Eligibility Criteria}

We included randomized clinical trials (RCTs) that compared intravenous iron with oral iron or no iron or placebo. We included studies from 1966 to January 31, 2021, that were included in the previous meta-analysis and conducted another search of studies published from January 1, 2013, until January 5,2021 , examining all relevant patient populations. We recognized that adverse events may not always be fully captured in RCTs. ${ }^{26}$ Therefore, we also searched for nonrandomized studies (NRSs) that met the following criteria: (1) report data on infection, (2) presence of at least 2 comparable groups, (3) quasi-RCTs, and (4) published since January 1, 2007. This date was chosen because this 
was the year that newer iron preparations (eg, ferric carboxymaltose and iron isomaltoside) received or renewed their marketing authorization.

Our primary outcome was the risk of infection. Secondary outcomes were differences in hemoglobin, RBC transfusion requirements, hospital length of stay, and short-term ( $\leq 30$ days) and long-term (>30 days) mortality.

\section{Search Methods and Study Selection}

An information specialist (C.D.) searched the following databases: Cochrane Central Register of Controlled Trials (CENTRAL) in The Cochrane Library, Medline, Embase, Cumulative Index to Nursing and Allied Health Literature (CINAHL), PubMed (e-publications ahead of print only), Web of Science (1990 onward), and the Transfusion Evidence Library (1950 onward). Ongoing trials were sought from ClinicalTrials.gov, CENTRAL, and World Health Organization International Clinical Trials Search Registry Platform. Key search terms included iron, ferric/ferrous compounds, and intravenous/I.V./ inject/parenteral. Only English-language articles were considered. The first search date was May 2 , 2018, and the last search date was January 5, 2021. The full search strategy is available in eAppendix 1 in the Supplement.

Literature searches were uploaded to Covidence, a web-based software platform, and 2 reviewers (A.A.S. and K.D.) independently screened study titles and abstracts for eligibility. The same 2 reviewers then independently screened the full text reports for inclusion. Disagreements were resolved through discussion.

\section{Data Extraction}

Data were extracted onto standardized and prepiloted forms for RCTs and NRSs by pairs of 2 reviewers (A.A.S. and K.D. as well as C.S. and E.A.D.) independently. The following data, if reported, on the outcome of infection were extracted: (1) definitions of infection used, (2) anatomical site of infection, (3) positive microbiology culture data, and (4) antibiotic use. Disagreements were resolved through discussion or referred to a third reviewer (S.J.S.). Study authors were contacted to resolve any uncertainties.

\section{Assessment of Risk of Bias}

Risk of bias for RCTs was assessed using the Cochrane Risk of Bias tool. ${ }^{27}$ Because of some of the potential costs and logistical difficulties associated with blinding intravenous iron preparations due to their rusty brown appearance, we made an a priori decision to classify open-label designs as low risk for detection bias for objective outcomes, such as changes in hemoglobin, mortality, and length of stay, in the absence of other concerns. For analysis and presentation purposes, a 3-point scale (low risk, some concerns, or high risk) was used to determine overall risk of bias for each study. Risk of bias for NRSs was assessed using the Risk of Bias in Nonrandomised Studies-of Interventions (ROBINS-I) tool developed by the Cochrane Bias Methods Group. ${ }^{28}$ All assessments were performed in duplicate by pairs of 2 independent reviewers (A.A.S. and K.D. as well as C.S. and E.A.D.).

\section{Data Synthesis}

The primary end point was the proportion of patients who developed an infection. Dichotomous outcomes (infection, mortality, and requirement for RBC transfusion) were reported as risk ratio (RR) with corresponding 95\% Cls. For continuous measures, we reported mean differences (MD) with $95 \%$ Cls. Data from RCTs that fulfilled the eligibility criteria were pooled for meta-analysis with a random-effects model. Statistical heterogeneity was measured using the $I^{2}$ statistic, and $l^{2}>50 \%$ was considered as showing substantial heterogeneity. ${ }^{29}$ Metaregression was undertaken to investigate the effect of baseline iron status (hemoglobin, ferritin, and transferrin saturation) on the risk of developing infection. Statistical analyses were conducted with RevMan software, version 5.3 (Cochrane Collaboration) and Stata software, version 14 (StataCorp LLC). A 2-sided $P<.05$ was considered statistically significant. For NRSs, we reported results on infection descriptively instead 
of pooling results because of heterogeneity in clinical conditions, study designs, and differences in adjusting for confounders. ${ }^{28} \mathrm{~A}$ narrative synthesis was performed to characterize the definitions of infection used, reporting of infection sources and pathogens, and antibiotic use.

\section{Subgroup and Sensitivity Analyses}

We hypothesized that certain clinical, biological, and therapeutic characteristics may predispose patients to an increased risk of infection. If sufficient data were available, we planned a priori to perform subgroup analyses on the following: (1) clinical settings or conditions (surgery, obstetrics, critical illness, CKD, IBD, heart failure, and pediatrics), (2) iron profiles at enrollment, (3) mode of administration (single dose or multiple doses), and (4) iron preparation used and cumulative dose of iron. We performed a sensitivity analysis for infection by only including trials judged to be at overall low risk of bias.

\section{Assessment of the Quality of the Evidence}

The GRADE (Grades of Recommendation, Assessment, Development, and Evaluation) ${ }^{30}$ approach was used to assess the overall quality of evidence for the primary outcome of infection. We assessed for publication bias on the primary outcome with a funnel plot if more than 10 RCTs were available, plotting the odds ratio for the proportion that develop infection against the SE of the log odds ratio.

\section{Results}

\section{Study Selection}

Our search identified 7656 records. We assessed 311 full-text articles for exclusion by screening of titles, duplicates, and abstracts (Figure 1). Details on all included and the 34 ongoing trials are available (Table 1; eTables 1 and 2 in the Supplement).

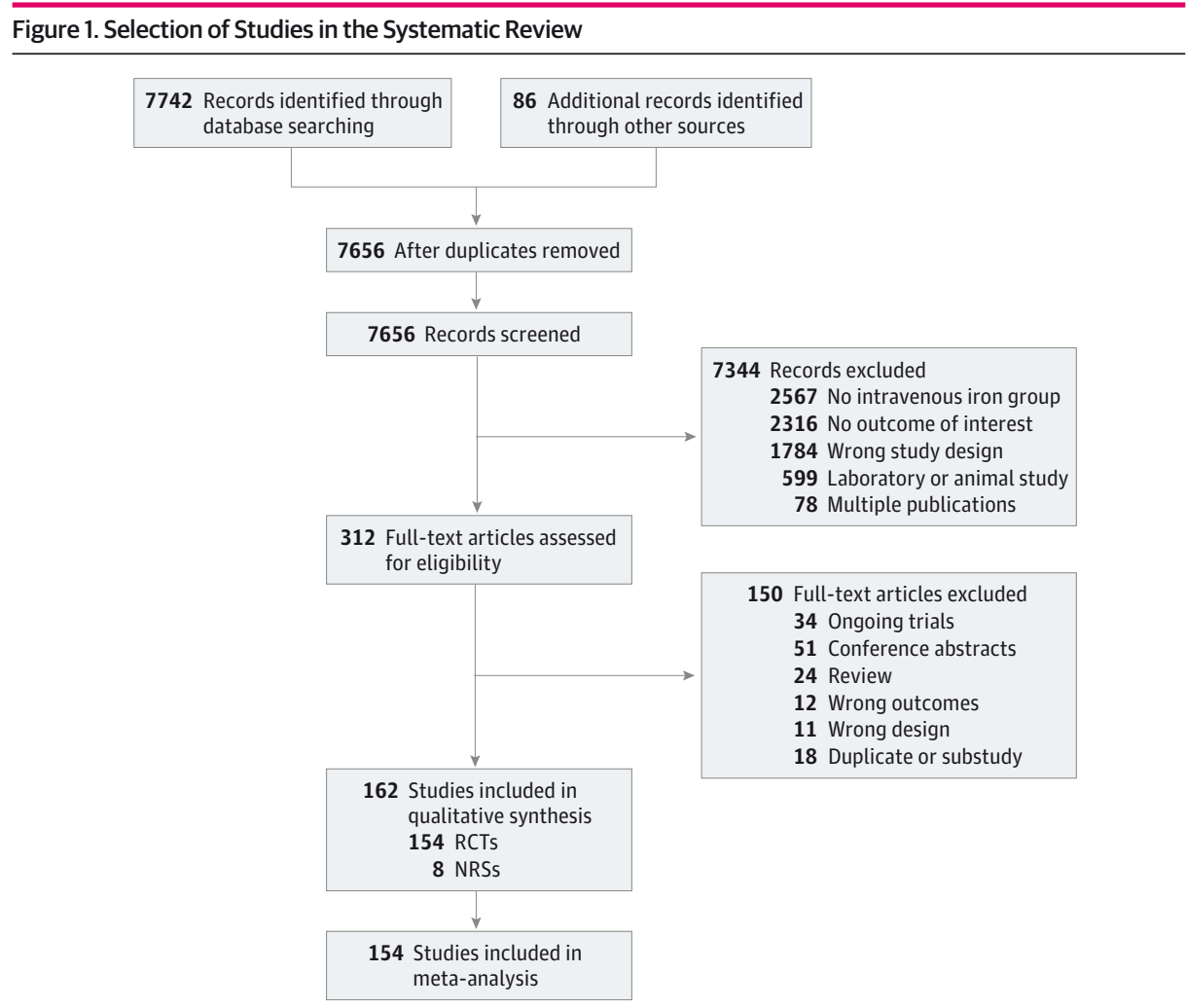




\section{Study Characteristics}

A total of 162 studies with 40066 participants were included in this systematic review, of which 154 were RCTs (32 920 participants) ${ }^{31-184}$ and 8 were NRSs (7146 participants). ${ }^{185-192}$ Two RCTs $^{47,106}$ were analyzed as 2 separate studies each. A descriptive summary, including study characteristics and

Table 1. Summary Characteristics of Included RCTs According to Geographic Location, Clinical Settings, and Type of Iron Preparation

\begin{tabular}{|c|c|c|c|}
\hline \multirow[b]{2}{*}{ Characteristic } & \multicolumn{3}{|l|}{ No. of RCTs } \\
\hline & Intravenous iron vs oral iron & $\begin{array}{l}\text { Intravenous iron vs no } \\
\text { iron }\end{array}$ & Total \\
\hline Single center & 51 & 30 & 81 \\
\hline Multicenter & 37 & 36 & 73 \\
\hline \multicolumn{4}{|l|}{ Geographic location } \\
\hline Australasia & 5 & 4 & 9 \\
\hline Europe & 25 & 31 & 56 \\
\hline Asia & 28 & 14 & 42 \\
\hline Africa & 4 & 0 & 4 \\
\hline North America & 17 & 16 & 33 \\
\hline South America & 2 & 1 & 3 \\
\hline Cross-continent & 6 & 1 & 7 \\
\hline \multicolumn{4}{|l|}{ Clinical setting } \\
\hline Blood donors & 1 & 2 & 3 \\
\hline CCF & 1 & 8 & 9 \\
\hline CKD & 16 & 6 & 22 \\
\hline Critical care & 0 & 5 & 5 \\
\hline Elite athletes & 0 & 2 & 2 \\
\hline IBD & 4 & 2 & 6 \\
\hline Mixed or general medical & 2 & 7 & 9 \\
\hline Menorrhagia & 1 & 2 & 3 \\
\hline Obstetrics & 39 & 0 & 39 \\
\hline \multicolumn{4}{|l|}{ Oncology } \\
\hline Hematology & 0 & 3 & 3 \\
\hline Nonhematology or solid organ & 8 & 5 & 13 \\
\hline Pediatric & 3 & 1 & 4 \\
\hline Restless legs & 0 & 7 & 7 \\
\hline Surgery & 10 & 17 & 27 \\
\hline Gastrointestinal bleeding & 0 & 2 & 2 \\
\hline \multicolumn{4}{|l|}{ Inclusion criteria } \\
\hline Iron deficiency anemia & 28 & 9 & 37 \\
\hline Functional iron deficiency & 20 & 14 & 34 \\
\hline Hemoglobin only & 31 & 25 & 56 \\
\hline Iron deficiency only & 3 & 7 & 10 \\
\hline Nonanemic & 4 & 2 & 6 \\
\hline Unclear & 2 & 9 & 11 \\
\hline \multicolumn{4}{|l|}{ Iron preparations evaluated } \\
\hline Ferric carboxymaltose & 21 & 30 & 51 \\
\hline Iron sucrose & 43 & 25 & 68 \\
\hline Iron dextran & 8 & 4 & 12 \\
\hline Iron isomaltoside & 4 & 3 & 7 \\
\hline Iron polymaltose & 3 & 0 & 3 \\
\hline Iron saccharate & 2 & 0 & 2 \\
\hline Ferumoxytol & 2 & 1 & 3 \\
\hline Ferric gluconate & 3 & 4 & 7 \\
\hline Not reported & 1 & 0 & 1 \\
\hline
\end{tabular}

Abbreviations: CCF, congestive cardiac failure; CKD, chronic kidney disease; IBD, inflammatory bowel disease; RCT, randomized clinical trial. 
risk of bias assessments, of NRSs that reported on outcomes of infection is provided in eAppendix 2

and eTables 3 and 4 in the Supplement.

The median number of participants in the included RCTs was 111 (IQR, 14-2534). Seventy-four

RCTs were multicenter, and studies were performed in a wide range of clinical settings (Table 1). The

most common settings were obstetrics (39 RCTs; 9993

participants), $31,32,37-39,49,50,53,55,56,63,64,73,74,76,79,81,83,88,91,95-97,104,105,111,129-131,140,148,152,157,160,167,172,174,177,182$

surgery (27 RCTs; 4223

participants), 54,57,58,61,80,89,99,101-103,107,109,111,126-129,136,138,139,151,154,159,163,178,181,183 and CKD (22 RCTs;

6013 participants). ${ }^{33-36,46,47,68,69,72,77,86,115,119,120,124,146,147,155,159,161,173}$ Trials were conducted across all

continents, with the most common location being Europe

(n = 56). 38,41,45,48,50,52-55,57,58,60-63,65,67,78,80,82,84,85,90,91,93,94,96,99,102-104,113,115,119,121,127,133,135,136,138,140,141,143,145,150,151,153-155,159,163,166,168,172,178,179

The most common iron preparations evaluated were iron sucrose

$(n=68)^{31-35,37-39,42,48-53,55,56,58,60,69,73,75,77,79-81,83,88,90-93,98,101,109,110,112,113,116-118,122-124,126,127,129-132,135,141-143,146,149,152,155,166,167,171,175,178,179,181,183 ~}$

and ferric carboxymaltose

(n = 51). 40,41,45-47,54,57,61-65,68,70,71,74,78,82,84,85,89,94,103,104,106-108,111,114,115,120,137-139,144,145,148,151,153,154,157,158,160,163,167,172,174,176,180,182

\section{Risk of Bias}

The overall risk of bias was low for 31

RCTs $41,45,46,51,54,58,67,70,72,103,104,108,111,113,120,125-129,137,139,145,147,151,159,163,167,170,180$ and high for 106 RCTs.

Twenty-two

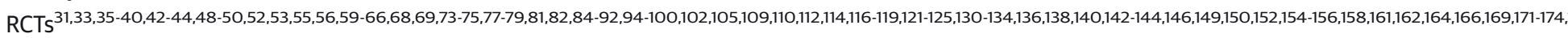

had some concerns for bias. The high risk of bias was most frequently attributable to insufficient

blinding of participants, study personnel, or outcome assessors or not providing sufficient

information for a decision. A total of 88 included

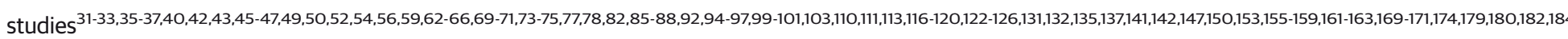
were also at high or unclear risk of bias for allocation concealment (eFigure 1 and eTable 5 in the

Supplement). Visual inspection of funnel plots for publication bias did not identify any concerns

(eFigure 2 in the Supplement).

\section{Primary Outcome}

Infection

Sixty-four

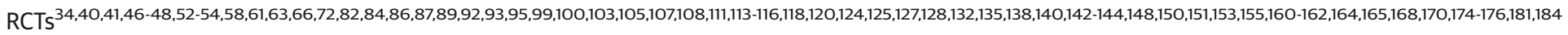

with 19480 participants provided sufficient data for analysis of our primary outcome. Intravenous

iron was associated with an increased risk of infection when compared with oral iron or no iron (RR,

1.17; 95\% Cl, 1.04-1.31; $I^{2}=37 \% ; P=.003$ ) (Table 2, Figure 2, and Figure 3). On the basis of the

GRADE framework, this finding was judged to be moderate-quality evidence. In absolute terms, 17

more people per 1000 population $(95 \% \mathrm{Cl}, 4-31)$ will experience an infection when intravenous iron

is used (eAppendix 3 in the Supplement). In the preplanned sensitivity analysis that excluded studies

at high risk of bias, the RR was $1.15\left(95 \% \mathrm{Cl}, 0.98-1.35 ; I^{2}=37 \% ; P=.07 ; 16 \mathrm{RCTs} ; 8719\right.$ participants)

(eFigure 3 in the Supplement).

Subgroup analysis by clinical setting found evidence of an increased risk of infection in patients with IBD (RR, 1.73; 95\% Cl, 1.11-2.71; $I^{2}=0 \% ; P=.02 ; 6 \mathrm{RCTs} ; 908$ participants) (eFigure 4 in the Supplement). ${ }^{82,114,115,118,150,155}$ We observed no evidence of an effect associated with iron or anemia profiles at study enrollment (as defined by the study authors) or type of iron preparation used. Both single- and multiple-dose administrations were associated with an increased risk of infection (eFigure 5 in the Supplement). Metaregression found no evidence of an interaction between baseline ferritin level, hemoglobin level, transferrin saturation, study year, and risk of infection (eTable 6 in the Supplement).

Significant variation was found in the definitions and reporting of infection across included studies (eTable 7 in the Supplement). Eight RCTs ${ }^{41,46,66,103,127,142,144,148}$ used an established 
classification system, with the most common one being the Medical Dictionary for Regulatory

Activities. ${ }^{193}$ Two trials used standardized Centers for Disease Control and Prevention definitions for nosocomial infections. Twenty-four

$\mathrm{RCTs}^{34,47,54,61,63,82,84,91,93,99,103,111,116,120,125,135,138,140,142,148,159,168,170}$ reported the anatomical site of infection, with the lung being the most common site. Seven RCTs ${ }^{87,107,108,128,132,159,181}$ had a pragmatic investigator-defined definition. Forty-nine

$\mathrm{RCTs}^{34,40,47,48,52-54,61,63,82,84,86,87,92,93,95,99,100,106,111,113-116,118,120,124,125,128,135,138,140,143,150,151,153,155,159,160,164,165,168,170,174,175,184}$

did not provide a definition a priori. There was less information on treatment of infections. One $\mathrm{RCT}^{143}$ reported data on antibiotic use between groups. No RCTs reported data on positive

microbiology cultures.

\section{Secondary Outcomes \\ Hemoglobin}

Hemoglobin data were available from 111

RCTs ${ }^{31-39,41-45,47,50,51,53-57,60-69,72-77,79-81,83,85,89-93,95,97-99,101-110,112,113,115-120,123,126,127,130-139,141,144,146-150,152,153,156-159,161,164,165,170,171,176,177,183,184 ~}$

with 20776 participants. When pooled, intravenous iron was associated with an increase in

hemoglobin at the end of the study period when compared with oral iron or no iron (MD, $0.57 \mathrm{~g} / \mathrm{dL}$;

$95 \% \mathrm{Cl}, 0.50-0.64 \mathrm{~g} / \mathrm{dL}$ [to convert to grams per liter, multiply by 10 ]; $I^{2}=94 \% ; P<.001$ ).

Intravenous iron was also associated with a treatment response, as defined by the study authors (eg, increase in hemoglobin of $>2 \mathrm{~g} / \mathrm{dL}$ ), when compared with oral iron or no iron (RR, $1.46 ; 95 \% \mathrm{Cl}, 1.32$ -

$1.60 ; l^{2}=92 \% ; P<.001$ ) (Table 2 ; eFigure 6 in the Supplement).

\section{RBC Transfusion Requirements}

Data on RBC transfusion requirements were available from 54

$\mathrm{RCTs}^{34,38,42,44,45,48,50,52-54,57,58,61,63,75,80,88-90,93,96,99,101,103,106-112,120,122,124,126-129,132-134,138-142,151,158,159,163,165,171,179,182}$

with 12116 participants. Intravenous iron was associated with a reduction in the risk of requiring an

$\mathrm{RBC}$ transfusion when compared with oral iron or no iron (RR, $0.93 ; 95 \% \mathrm{Cl}, 0.76-0.89 ; I^{2}=15 \%$;

$P<.001)$ and a lower number of mean RBCs transfused when compared with no iron (MD, -0.20 ;

$95 \% \mathrm{Cl},-0.32$ to $-0.08 ; I^{2}=81 \% ; P<.001$ ) (Table 2 ; eFigure 7 in the Supplement).

\begin{tabular}{|c|c|c|c|c|c|c|}
\hline \multirow[b]{2}{*}{ Outcome } & \multirow[b]{2}{*}{ No. of studies } & \multicolumn{2}{|l|}{ No. of participants ${ }^{a}$} & \multirow[b]{2}{*}{ Treatment effect } & \multirow[b]{2}{*}{$P$ value } & \multirow[b]{2}{*}{$I^{2}, \%$} \\
\hline & & Intravenous iron & Oral iron or no iron & & & \\
\hline Infection & 64 & $1102 / 10089$ & $950 / 9391$ & $\mathrm{RR}(95 \% \mathrm{Cl}): 1.17$ (1.04 to 1.31$)$ & .003 & 37 \\
\hline \multicolumn{7}{|l|}{ Continuous outcomes } \\
\hline Hemoglobin & 110 & 10816 & 9720 & MD (95\% Cl): $0.57(0.50$ to 0.64$) \mathrm{g} / \mathrm{dL}$ & $<.001$ & 94 \\
\hline \multicolumn{7}{|l|}{ Dichotomous outcomes } \\
\hline Treatment response ${ }^{\mathrm{b}}$ & 60 & $4336 / 7137$ & $2611 / 6165$ & $\operatorname{RR}(95 \% \mathrm{Cl}): 1.46(1.32$ to 1.60$)$ & $<.001$ & 92 \\
\hline \multicolumn{7}{|l|}{ Mortality } \\
\hline Short term $(\leq 30 \mathrm{~d})$ & 15 & $40 / 1298$ & $40 / 1292$ & $\operatorname{RR}(95 \% \mathrm{Cl}): 0.99$ (0.69 to 1.42$)$ & .73 & 0 \\
\hline Long term (>30 d) & 12 & $165 / 2752$ & $161 / 2258$ & $\operatorname{RR}(95 \% \mathrm{Cl}): 0.94$ (0.75 to 1.18$)$ & .63 & 0 \\
\hline \multicolumn{7}{|c|}{ SI conversion factor: To convert hemoglobin to grams per liter, multiply by 10 . } \\
\hline \multicolumn{7}{|c|}{$\begin{array}{l}\text { a Number for primary and dichotomous outcomes indicates number of events divided } \\
\text { by the total number of participants. }\end{array}$} \\
\hline
\end{tabular}




\section{Mortality}

We observed no evidence of an association of intravenous iron with short-term (RR, $0.99 ; 95 \% \mathrm{Cl}$, $0.69-1.42 ; I^{2}=0 \% ; P=.73 ; 15 \mathrm{RCTs} ; 3445$ participants) or long-term mortality (RR, 0.94; 95\% Cl, $0.75-1.18 ; I^{2}=0 \% ; P=.63 ; 12 \mathrm{RCTs} ; 5010$ participants) when compared with oral iron or no iron (Table 2; eFigure 8 in the Supplement).

\section{Hospital Length of Stay}

There was no evidence of an association of intravenous iron with hospital length of stay when compared with oral iron or no iron (MD, -0.43 days; $95 \% \mathrm{Cl},-1.10$ to 0.24 days; $I^{2}=50 \% ; P=.05 ; 8$ RCTs; 1690 participants) (Table 2; eFigure 8 in the Supplement).

\section{Discussion}

\section{Key Findings}

Our systematic review and meta-analysis identified 154 RCTs $s^{31-182}$ across a range of clinical settings.

The main findings were (1) intravenous iron was associated with an increased risk of infection (moderate certainty of evidence); (2) there was substantial variation and inconsistency in how infection was defined and reported; and (3) intravenous iron remained associated with improved hemoglobin levels and reduced RBC transfusion requirements. Although we observed no differences

Figure 2. Association Between Risk of Infection and Intravenous Iron When Compared With Oral Iron

\begin{tabular}{|c|c|c|c|c|c|c|c|c|c|c|}
\hline \multirow{3}{*}{ Study } & \multicolumn{2}{|c|}{ Experimental } & \multicolumn{2}{|l|}{ Control } & \multirow{3}{*}{ Risk ratio $(95 \% \mathrm{Cl})$} & \multirow{3}{*}{\multicolumn{2}{|c|}{$\begin{array}{r}\text { Favors } \\
\text { comparator }\end{array}$}} & \multirow{3}{*}{$\begin{array}{l}\text { Favors } \\
\text { intervention }\end{array}$} & \multirow{3}{*}{$\begin{array}{l}\text { Weight, } \\
\%\end{array}$} & \multirow{3}{*}{ Risk of bias } \\
\hline & No. of & Total & No. of & Total & & & & & & \\
\hline & & & & & & & & & & \\
\hline Agarwal et al, ${ }^{34} 2015$ & 37 & 67 & 27 & 69 & $1.41(0.98-2.03)$ & & & $=$ & 10.6 & 0000000 \\
\hline Bencaiova et al, 532009 & 9 & 130 & 1 & 130 & $9.00(1.16-70.03)$ & & & $\longrightarrow$ & 0.4 & $0000 ? 00$ \\
\hline Bisbe et al, 612014 & 4 & 60 & 0 & 62 & $9.30(0.51-169.01)$ & & & & 0.2 & $000 ? 000$ \\
\hline Breymann et al, 632008 & 19 & 277 & 4 & 177 & $3.04(1.05-8.77)$ & & & & 1.6 & $? 0 \bigcirc ? 000$ \\
\hline Fishbane et al, ${ }^{86} 1995$ & 2 & 25 & 5 & 50 & $0.80(0.17-3.84)$ & & & & 0.8 & ?อ०??० \\
\hline Henry et al, ${ }^{95} 2007$ & 6 & 41 & 16 & 88 & $0.80(0.34-1.91)$ & & & 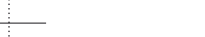 & 2.4 & 2000000 \\
\hline Kalra et al,100 2016 & 56 & 112 & 53 & 117 & $1.10(0.84-1.45)$ & & & $=$ & 15.8 & $0 ? 0 ? 000$ \\
\hline Keeler et al, 1032017 & 36 & 55 & 31 & 61 & $1.29(0.94-1.76)$ & & & - & 13.2 & 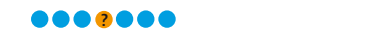 \\
\hline Khalafallah et al, ${ }^{105} 2010$ & 0 & 92 & 0 & 91 & Not estimable & & & & & 000000 \\
\hline Kulnigg et al, ${ }^{114} 2008$ & 18 & 137 & 6 & 63 & $1.38(0.58-3.31)$ & & & $\rightarrow$ & 2.4 & 000000 \\
\hline Lindgren et al,118 2009 & 12 & 45 & 4 & 46 & $3.07(1.07-8.80)$ & & & & 1.6 & 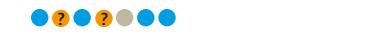 \\
\hline MacDougall et al, ${ }^{120} 2014$ & 114 & 304 & 111 & 312 & $1.05(0.86-1.30)$ & & & - & 21.2 & ○०९००० \\
\hline Meyer et al, 1241996 & 2 & 21 & 2 & 21 & $1.00(0.16-6.45)$ & & & & 0.5 & $? ? 000 ? 0$ \\
\hline Mudge et al, ${ }^{128} 2012$ & 10 & 51 & 12 & 51 & $0.83(0.40-1.75)$ & & & 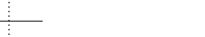 & 3.2 & 0000000 \\
\hline Neogi et al, 1322019 & 13 & 934 & 13 & 947 & $1.01(0.47-2.18)$ & & & & 3.0 & $\bullet \bullet \bullet \bullet \bullet$ \\
\hline Padmanabhan et al, 1382019 & 4 & 20 & 5 & 20 & $0.80(0.25-2.55)$ & & & & 1.4 & $000 \bullet \bullet ० ०$ \\
\hline Pollak et al, ${ }^{143} 2001$ & 2 & 10 & 4 & 19 & $0.95(0.21-4.32)$ & & & & 0.8 & $? 00 ? 0 ?$ \\
\hline Qunibi et al, ${ }^{148} 2011$ & 20 & 147 & 8 & 103 & $1.75(0.80-3.82)$ & & & & 2.9 & 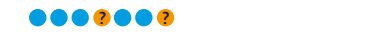 \\
\hline Reinisch et al, 1502013 & 1 & 233 & 0 & 109 & $1.41(0.06-34.34)$ & & & & 0.2 & $000 ? 000$ \\
\hline Schröder et al, ${ }^{155} 2005$ & 2 & 22 & 0 & 24 & $5.43(0.28-107.33)$ & & & & 0.2 & $0 ? 0 ? 000$ \\
\hline Singh et al, ${ }^{161} 1998$ & 0 & 30 & 0 & 30 & Not estimable & & & & & $? ? \bigcirc ? \bullet \bigcirc ?$ \\
\hline Steensma et al, 1652011 & 28 & 164 & 11 & 163 & $2.53(1.30-4.91)$ & & & & 3.9 & $000000 ?$ \\
\hline Van Wyck et al,175 2005 & 2 & 79 & 0 & 82 & $5.19(0.25-106.38)$ & & & & 0.2 & 0000000 \\
\hline Van Wyck et al, ${ }^{174} 2007$ & 24 & 174 & 22 & 178 & $1.12(0.65-1.91)$ & & & - & 5.6 & 0000000 \\
\hline Vanobberghen et al, 1762021 & 32 & 114 & 25 & 116 & $1.30(0.83-2.05)$ & & & - & 7.5 & 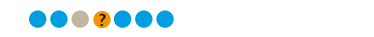 \\
\hline Verma et al, ${ }^{184} 2011$ & 1 & 75 & 0 & 75 & $3.00(0.12-72.49)$ & & & & 0.2 & 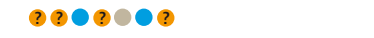 \\
\hline Total $(95 \% \mathrm{Cl})$ & & 3419 & & 3204 & $1.26(1.09-1.44)$ & & & $\diamond$ & 100.0 & A Random sequence generation \\
\hline Total events & 454 & & 360 & & & & . & पालामामा & & (selection bias) \\
\hline $\begin{array}{l}\text { Heterogeneity: } \tau^{2}=0.01 ; \chi^{2}=2 \\
\text { Test for overall effect: } z=3.24 \\
\text { Test for subgroup differences: }\end{array}$ & $\begin{array}{l}6.04, d f= \\
(P=.001) \\
\text { not applic }\end{array}$ & $\begin{array}{l}=23(P= \\
\text { cable }\end{array}$ & $=.30) ; 1^{2}$ & $=12 \%$ & & $\begin{array}{llll}0.06 & 0.1 & 0.2\end{array}$ & $\begin{array}{l}0.5 \\
\text { Risk }\end{array}$ & $\begin{array}{ccccc}1 & 2 & 5 & 10 & 11 \\
\text { ratio, } \% & & & \end{array}$ & & $\begin{array}{l}\text { B Allocation concealment (selection bias) } \\
\text { C Blinding of participants and personnel } \\
\text { (performance bias) } \\
\text { D Blinding of outcome assessment } \\
\text { (detection bias) } \\
\text { E Incomplete outcome data (attrition bias) } \\
\text { F Selective reporting (reporting bias) } \\
\text { G Other bias }\end{array}$ \\
\hline
\end{tabular}

The risk ratios were calculated using a random-effects model with Mantel-Haenszel weighting. The size of the data markers indicates the weight of the study. Error bars indicate $95 \%$ Cls. Orange indicates unclear risk of bias; blue, low risk of bias; and grey, high risk of bias. 
in mortality or hospital length of stay, the $95 \%$ Cls were wide and could encompass clinically important differences.

Previous systematic reviews ${ }^{21,22,194}$ have summarized the evidence of superior efficacy for intravenous iron over oral iron or no iron but have less rigorously evaluated or reported the risk of infection. Two earlier systematic reviews ${ }^{21,22}$ have reported on the risks of infection but were based on much smaller numbers of RCTs. One review ${ }^{22}$ identified an increased risk of infection (RR, 1.34; 95\% Cl, 1.10-1.64; 24 RCTs; 4400 participants); the other review ${ }^{21}$ pooled data from 32 RCTs and found a point estimate that favored infection, although the finding was statistically nonsignificant (RR, 1.17; 95\% Cl, 0.83-1.65).

There is biological plausibility for increased rates of infection in patients receiving iron. ${ }^{13}$ Iron is required for growth by almost all human pathogens. ${ }^{11,13}$ Intravenous iron administration can lead to

Figure 3. Association Between Risk of Infection and Intravenous Iron When Compared With No Iron

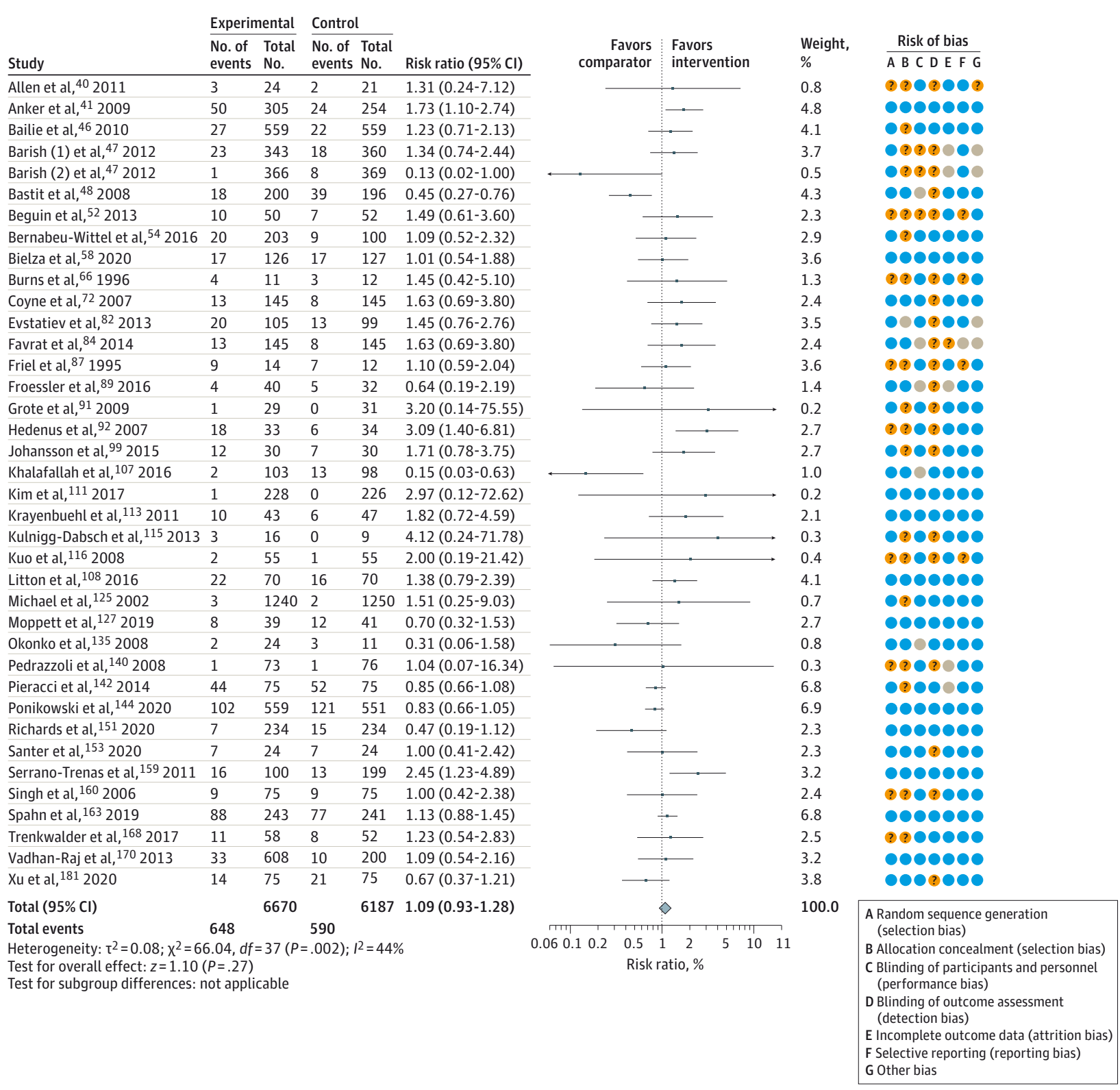

The size of the data markers indicates the weight of the study. Error bars indicate $95 \%$ Cls. Orange indicates unclear risk of bias; blue, low risk of bias; and grey, high risk of bias. 
increased levels of non-transferrin-bound iron, which is associated with impaired T-cell and neutrophil function, worsening organ function in preclinical and clinical studies, and increased pathogen growth. ${ }^{195,196}$ Conversely, preexisting iron deficiency or restriction can impair T-cell, B-cell, and neutralizing antibody responses to infection. ${ }^{197}$ These risks may be further expanded in patients with IBD in whom the prevalence of iron deficiency has been reported to be as high as $90 \%{ }^{20}$ and who may also be more susceptible to infection because of the increasing use of immunosuppressive and biological drugs. ${ }^{198,199}$ Although there was no statistical evidence of an increased risk in subgroups other than IBD, the point estimate favored increased infection rates in nearly all groups.

We identified significant variation and inconsistency in the reporting of infection despite the availability of standardized definitions. ${ }^{200}$ Of the 34 ongoing RCTs, 13 have prespecified infectionrelated outcomes. Of these, 9 RCTs do not have a definition, 2 have an investigator-defined definition, and 2 are using the Clavien-Dindo Classification system (eTable 2 in the Supplement). ${ }^{201}$ Reasons for this poor uptake are unclear but may include limitations with validity, reliability, and practicality. Recent initiatives, such as the updated Sepsis-3 definition ${ }^{202}$ and the Standardised Endpoints in Perioperative Medicine initiative, ${ }^{203}$ have sought to address these limitations and bring consistency to reporting infection. No studies reported data on pathogens or positive microbiology results. This lack of microbiology results has important clinical and mechanistic implications on understanding whether exogenous iron can convert benign bacterial colonization into virulent infection. Common commensal bacteria that are frequently implicated in nosocomial infection, such as Staphylococcus aureus and Staphylococcus epidermidis, have developed iron acquisition mechanisms and can become pathogenic under suitable conditions. ${ }^{10,13}$

Imbalances of iron homeostasis, including both iron deficiency and overload, can affect the risk of developing infection, but the effect of therapeutic iron on this remains unclear. ${ }^{204}$ The effects are likely to be context specific, depending on the patient's preexisting iron status, exposure to potential infections and genetic background, and type of iron preparation administerd. ${ }^{205,206}$ We observed no evidence of an interaction between baseline iron status (as measured by ferritin, transferrin saturation, and hemoglobin) and the risk of developing infection, although the number of studies reporting this information in a way that could be analyzed for metaregression ranged from 29 to 40. Trial data from patients with CKD undergoing maintenance hemodialysis ${ }^{207}$ suggest that a highdose intravenous iron regimen may be safe in patients with ferritin concentrations up to $700 \mathrm{ng} / \mathrm{mL}$ (to convert to micrograms per liter, multiply by 1 ), but data above this threshold are conflicting. ${ }^{20}$ The proportion of low free iron concentrations of the total dose of iron in newer intravenous iron preparations is thought to be associated with a lower risk of infection, which may be one reason why our subgroup analysis by type of preparation demonstrated no superiority of one preparation over another.

\section{Implications for Practice}

Our findings have broad applicability to many patients in whom iron deficiency and anemia are common. Clinical guidelines increasingly advocate the use of intravenous iron, and clinicians and policy makers should recognize that the benefits of treating anemia may need to be balanced against the risk of developing infection. These issues appear more pertinent in clinical settings with high endemic infection burdens where iron supplementation may be neither effective nor safe. ${ }^{206}$

\section{Implications for Research}

This review reinforces the need to quantify all relative risks more precisely alongside the benefits of intravenous iron. Part of the uncertainty around the risk of infection arises from variation and inconsistency in reporting this outcome, despite the availability of standardized definitions. Future trials should be adequately powered and robust, implement standardized definitions for outcomes of infections and focus on hypothesis testing mechanistic studies, such as the interactions between specific pathogens and host iron status on the risk of developing infection. 


\section{Strengths and Limitations}

This review has strengths. Its main strength is the strict methodologic process. We followed Cochrane Collaboration, PRISMA, and GRADE recommendations, performed 2 comprehensive searches, and used duplicate data extraction and risk of bias assessments. Compared with the previous reviews, ${ }^{21,22}$ we sought to further characterize the risk of infection and performed clinically relevant subgroup analyses, extracted data on how infection was reported, and included NRSs.

This study also has limitations, which can be attributed to the clinical and methodological differences and variations in infection reporting between the included studies, which may limit the understanding of the nature and true extent of the risk of infection. Updating the previous systematic review $^{22}$ may lead to type 1 error as a result of multiplicity attributable to repeated significance testing. Although we identified an improvement in hemoglobin levels, we did not assess whether this improvement translated into improved health-related quality of life, although this has been investigated by others. ${ }^{208}$ The quality of the included studies was also variable. Nevertheless, a sensitivity analysis including only trials at low risk of bias had minimal effect on the pooled estimate, and the heterogeneity calculation for outcomes of infection and RBC transfusion was not substantial.

\section{Conclusions}

In this systematic review and meta-analysis, intravenous iron administration was associated with an increased risk of infection, which must be considered alongside the potential benefit of treating anemia. Well-designed studies, using standardized definitions of infection, are needed to reduce the uncertainty about this particular risk.

\section{ARTICLE INFORMATION}

Accepted for Publication: September 13, 2021.

Published: November 12, 2021. doi:10.1001/jamanetworkopen.2021.33935

Open Access: This is an open access article distributed under the terms of the CC-BY License. (C) 2021 Shah AA et al. JAMA Network Open.

Corresponding Author: Akshay A. Shah, MSc, Radcliffe Department of Medicine, John Radcliffe Hospital, Headley Way, Level 4 Academic Block, Oxford OX3 9DU, United Kingdom (akshay.shah@linacre.ox.ac.uk).

Author Affiliations: Radcliffe Department of Medicine, University of Oxford, Oxford, United Kingdom (Shah, Stanworth); National Institute for Health Research Biomedical Research Centre Haematology Theme, Oxford, United Kingdom (Shah, Stanworth); Adult Intensive Care Unit, Oxford University Hospitals National Health Service (NHS) Foundation Trust, Oxford, United Kingdom (Shah, Donovan); Department of Anaesthesia, Royal Berkshire Hospitals NHS Foundation Trust, Reading, United Kingdom (Seeley); National Institute for Health Research Biomedical Research Centre in Gastrointestinal and Liver Diseases, Nottingham University Hospitals NHS Trust, Nottingham, United Kingdom. (Dickson, Acheson); Department of Colorectal Surgery, Nottingham University Hospitals NHS Trust, University of Nottingham, Nottingham, United Kingdom. (Dickson, Acheson); Nuffield Department of Orthopaedics, Rheumatology and Musculoskeletal Sciences, University of Oxford, Oxford, United Kingdom (Palmer); Systematic Review Initiative, NHS Blood \& Transplant, Oxford, United Kingdom (Doree, Brunskill, Stanworth); Department of Anaesthesia, Brighton and Sussex University Hospitals NHS Trust, Brighton, United Kingdom (Reid, Sugavanam); Intensive Care Unit, Fiona Stanley Hospital, Perth, Australia (Litton); Department of Haematology, Oxford University Hospitals NHS Foundation Trust, Oxford, United Kingdom (Stanworth).

Author Contributions: Dr Shah had full access to all the data in the study and takes responsibility for the integrity of the data and the accuracy of the data analysis.

Concept and design: Shah, Dickson, Palmer, Brunskill, Acheson, Sugavanam, Litton, Stanworth.

Acquisition, analysis, or interpretation of data: Shah, Donovan, Seeley, Dickson, Palmer, Doree, Reid, Litton, Stanworth.

Drafting of the manuscript: Shah, Donovan, Dickson, Palmer, Doree, Sugavanam, Stanworth. 
Critical revision of the manuscript for important intellectual content: Shah, Donovan, Seeley, Dickson, Palmer, Brunskill, Reid, Acheson, Sugavanam, Litton, Stanworth.

Statistical analysis: Shah, Donovan, Sugavanam, Litton.

Obtained funding: Shah, Stanworth.

Administrative, technical, or material support: Shah, Dickson, Palmer, Doree, Brunskill, Reid, Sugavanam.

Supervision: Brunskill, Acheson, Sugavanam, Litton, Stanworth.

Conflict of Interest Disclosures: Dr Acheson reported receiving grant support from Syner-Med (UK), Vifor Pharma (Switzerland), and Pharmacosmos A/S (Denmark) and honoraria and travel support for consulting or lecturing from Ethicon Endosurgery (UK), Johnson and Johnson Ltd (UK), Olympus (UK), and Vifor Pharma (Switzerland) outside the submitted work. No other disclosures were reported.

Funding/Support: Dr Shah is currently supported by National Institute for Health Research Doctoral Research Fellowship NIHR-DRF-2017-10-094.

Role of the Funder/Sponsor: The funding source had no role in the design and conduct of the study; collection, management, analysis, and interpretation of the data; preparation, review, or approval of the manuscript; and decision to submit the manuscript for publication.

Additional Contributions: Ravi Rao Baikady, MBBS, The Royal Marsden NHS Foundation Trust, London, UK, Chales M. Oliver, PhD, University College London, London, UK, and Sohail Bampoe, MBBS, University College London Hospitals NHS Foundation Trust, London, UK, provided initial input into the design of the study. Barrie Keeler, PhD, Milton Keynes University Hospitals NHS Foundation Trust, Buckinghamshire, UK, and lain Moppett, DM, University of Nottingham, Nottingham, UK, provided additional study data for this systematic review. They were not compensated for their work.

\section{REFERENCES}

1. Muñoz $M$, Acheson AG, Auerbach $M$, et al. International consensus statement on the peri-operative management of anaemia and iron deficiency. Anaesthesia. 2017;72(2):233-247. doi:10.1111/anae.13773

2. Muñoz M, Acheson AG, Bisbe $E$, et al. An international consensus statement on the management of postoperative anaemia after major surgical procedures. Anaesthesia. 2018;73(11):1418-1431. doi:10.1111/anae.14358

3. Pavord S, Daru J, Prasannan $\mathrm{N}$, et al. UK guidelines on the management of iron deficiency in pregnancy. $\mathrm{Br} J$ Haematol. 2019;188(6):819-830. doi:10.1111/bjh.16221

4. Aapro M, Beguin Y, Bokemeyer C, et al; ESMO Guidelines Committee. Management of anaemia and iron deficiency in patients with cancer: ESMO clinical practice guidelines. Ann Oncol. 2018;29(suppl 4):iv96-iv110. doi: 10.1093/annonc/mdx758

5. Mikhail A, Brown C, Williams JA, et al. Renal association clinical practice guideline on anaemia of chronic kidney disease. BMC Nephrol. 2017;18(1):345. doi:10.1186/s12882-017-0688-1

6. Mueller MM, Van Remoortel H, Meybohm P, et al; ICC PBM Frankfurt 2018 Group. Patient blood management: recommendations from the 2018 Frankfurt Consensus Conference. JAMA. 2019;321(10):983-997. doi:10.1001/ jama.2019.0554

7. Ponikowski P, Voors AA, Anker SD, et al; ESC Scientific Document Group. 2016 ESC Guidelines for the diagnosis and treatment of acute and chronic heart failure: The Task Force for the diagnosis and treatment of acute and chronic heart failure of the European Society of Cardiology (ESC) Developed with the special contribution of the Heart Failure Association (HFA) of the ESC. Eur Heart J. 2016;37(27):2129-2200. doi:10.1093/eurheartj/ehw128

8. Wang C, Graham DJ, Kane RC, et al. Comparative risk of anaphylactic reactions associated with intravenous iron products. JAMA. 2015;314(19):2062-2068. doi:10.1001/jama.2015.15572

9. Litton E, Lim J. Iron metabolism: an emerging therapeutic target in critical illness. Crit Care. 2019;23(1):81. doi: 10.1186/s13054-019-2373-1

10. Cassat JE, Skaar EP. Iron in infection and immunity. Cell Host Microbe. 2013;13(5):509-519. doi:10.1016/j.chom. 2013.04.010

11. Drakesmith H, Prentice AM. Hepcidin and the iron-infection axis. Science. 2012;338(6108):768-772. doi:10.

1126/science.1224577

12. Ganz T. Systemic iron homeostasis. Physiol Rev. 2013;93(4):1721-1741. doi:10.1152/physrev.00008.2013

13. Youssef LA, Spitalnik SL. Iron: a double-edged sword. Transfusion. 2017;57(10):2293-2297. doi:10.1111/

trf.14296

14. Shand AW, Bell J, Henry $A$, et al. Rapid increase in intravenous iron therapy for women of reproductive age in Australia. Med J Aust. 2020;213(2):85-86. doi:10.5694/mja2.50618 
15. Winkelmayer WC, Mitani AA, Goldstein BA, Brookhart MA, Chertow GM. Trends in anemia care in older patients approaching end-stage renal disease in the United States (1995-2010). JAMA Intern Med. 2014;174(5):699-707. doi:10.1001/jamainternmed.2014.87

16. Auerbach $M$, Deloughery $T$. Single-dose intravenous iron for iron deficiency: a new paradigm. Hematology Am Soc Hematol Educ Program. 2016;2016(1):57-66. doi:10.1182/asheducation-2016.1.57

17. Berríos-Torres SI, Umscheid CA, Bratzler DW, et al; Healthcare Infection Control Practices Advisory Committee. Centers for Disease Control and Prevention guideline for the prevention of surgical site infection, 2017. JAMA Surg. 2017;152(8):784-791. doi:10.1001/jamasurg.2017.0904

18. Wan $\mathrm{Y}$, Patel A, Abbott TEF, et al. Prospective observational study of postoperative infection and outcomes after noncardiac surgery: analysis of prospective data from the VISION cohort. Br J Anaesth. 2020;125(1):87-97. doi:10.1016/j.bja.2020.03.027

19. Zimlichman $\mathrm{E}$, Henderson $\mathrm{D}$, Tamir $\mathrm{O}$, et al. Health care-associated infections: a meta-analysis of costs and financial impact on the US health care system. JAMA Intern Med. 2013;173(22):2039-2046. doi:10.1001/ jamainternmed.2013.9763

20. Ganz T, Aronoff GR, Gaillard CAJM, et al. Iron administration, infection, and anemia management in CKD: untangling the effects of intravenous iron therapy on immunity and infection risk. Kidney Med. 2020;2(3): 341-353. doi:10.1016/j.xkme.2020.01.006

21. Avni T, Bieber A, Grossman A, Green H, Leibovici L, Gafter-Gvili A. The safety of intravenous iron preparations: systematic review and meta-analysis. Mayo Clin Proc. 2015;90(1):12-23. doi:10.1016/j.mayocp.2014.10.007

22. Litton $\mathrm{E}$, Xiao J, Ho KM. Safety and efficacy of intravenous iron therapy in reducing requirement for allogeneic blood transfusion: systematic review and meta-analysis of randomised clinical trials. BMJ. 2013;347:f4822. doi: 10.1136/bmj.f4822

23. Miles LF. The end of the beginning: pre-operative intravenous iron and the PREVENTT trial. Anaesthesia. 2021;76(1):6-10. doi:10.1111/anae.15268

24. Numan S, Kaluza K. Systematic review of guidelines for the diagnosis and treatment of iron deficiency anemia using intravenous iron across multiple indications. Curr Med Res Opin. 2020;36(11):1769-1782. doi:10.1080/ 03007995.2020.1824898

25. Shah A, Sugavanam A, Reid J, et al. Risk of infection associated with intravenous iron preparations: protocol for updating a systematic review. BMJ Open. 2019;9(6):e024618. doi:10.1136/bmjopen-2018-024618

26. Golder S, Loke YK, Wright K, Norman G. Reporting of adverse events in published and unpublished studies of health care interventions: a systematic review. PLoS Med. 2016;13(9):e1002127. doi:10.1371/journal.pmed.1002127

27. Higgins JP, Altman DG, Gøtzsche PC, et al; Cochrane Bias Methods Group; Cochrane Statistical Methods Group. The Cochrane Collaboration's tool for assessing risk of bias in randomised trials. BMJ. 2011;343:d5928. doi: 10.1136/bmj.d5928

28. Sterne JA, Hernán MA, Reeves BC, et al. ROBINS-I: a tool for assessing risk of bias in non-randomised studies of interventions. BMJ. 2016;355:i4919. doi:10.1136/bmj.i4919

29. Higgins JPT, Green S. Cochrane Handbook for Systematic Reviews of Interventions. Wiley; 2011.

30. Atkins D, Best D, Briss PA, et al; GRADE Working Group. Grading quality of evidence and strength of recommendations. BMJ. 2004;328(7454):1490. doi:10.1136/bmj.328.7454.1490

31. Abdelazim I, Abu-Faza M, Elbiaa A, Othman H, Alsharif D, Elsawah W. Heme iron polypeptide (proferrin\&\#174;-ES) versus iron saccharate complex (ferrosac) for treatment of iron deficiency anemia during pregnancy. Acta Medica International. 2017;4(1):56-61. doi:10.5530/ami.2017.4.11

32. Abhilashini GD, Sagili H, Reddi R. Intravenous iron sucrose and oral iron for the treatment of iron deficiency anaemia in pregnancy. J Clin Diagn Res. 2014;8(5):OC04-OCO7.

33. Adhikary L, Acharya S. Efficacy of IV iron compared to oral iron for increment of haemoglobin level in anemic chronic kidney disease patients on erythropoietin therapy. JNMA J Nepal Med Assoc. 2011;51(183):133-136. doi:10. 31729/jnma.32

34. Agarwal R, Kusek JW, Pappas MK. A randomized trial of intravenous and oral iron in chronic kidney disease. Kidney Int. 2015;88(4):905-914. doi:10.1038/ki.2015.163

35. Agarwal R, Rizkala AR, Bastani B, Kaskas MO, Leehey DJ, Besarab A. A randomized controlled trial of oral versus intravenous iron in chronic kidney disease. Am J Nephrol. 2006;26(5):445-454. doi:10.1159/000096174

36. Aggarwal HK, Nand N, Singh S, Singh M, Hemant, Kaushik G. Comparison of oral versus intravenous iron therapy in predialysis patients of chronic renal failure receiving recombinant human erythropoietin. $J$ Assoc Physicians India. 2003;51:170-174. 
37. Akhtar T, Shaikh SN, Soomro SB. Parenteral versus oral iron therapy in postpartum anemia. Medical Forum Monthly. 2018;29(12):87-90.

38. Al RA, Unlubilgin E, Kandemir O, Yalvac S, Cakir $L$, Haberal A. Intravenous versus oral iron for treatment of anemia in pregnancy: a randomized trial. Obstet Gynecol. 2005;106(6):1335-1340. doi:10.1097/01.AOG. 0000185260.82466.b4

39. al-Momen AK, al-Meshari A, al-Nuaim L, et al. Intravenous iron sucrose complex in the treatment of iron deficiency anemia during pregnancy. Eur J Obstet Gynecol Reprod Biol. 1996;69(2):121-124. doi:10.1016/0301-2115 (95)02538-3

40. Allen RP, Adler CH, Du W, Butcher A, Bregman DB, Earley CJ. Clinical efficacy and safety of IV ferric carboxymaltose (FCM) treatment of RLS: a multi-centred, placebo-controlled preliminary clinical trial. Sleep Med. 2011;12(9):906-913. doi:10.1016/j.sleep.2011.06.009

41. Anker SD, Comin Colet J, Filippatos G, et al; FAIR-HF Trial Investigators. Ferric carboxymaltose in patients with heart failure and iron deficiency. N Engl J Med. 2009;361(25):2436-2448. doi:10.1056/NEJMoa0908355

42. Athibovonsuk $P$, Manchana $T$, Sirisabya N. Prevention of blood transfusion with intravenous iron in gynecologic cancer patients receiving platinum-based chemotherapy. Gynecol Oncol. 2013;131(3):679-682. doi:10. 1016/j.ygyno.2013.09.028

43. Auerbach $\mathrm{M}$, Ballard $\mathrm{H}$, Trout $\mathrm{JR}$, et al. Intravenous iron optimizes the response to recombinant human erythropoietin in cancer patients with chemotherapy-related anemia: a multicenter, open-label, randomized trial. J Clin Oncol. 2004;22(7):1301-1307. doi:10.1200/JCO.2004.08.119

44. Auerbach M, Silberstein PT, Webb RT, et al. Darbepoetin alfa 300 or $500 \mu$ g once every 3 weeks with or without intravenous iron in patients with chemotherapy-induced anemia. Am J Hematol. 2010;85(9):655-663. doi:10.1002/ajh.21779

45. Bager $P$, Dahlerup JF. Randomised clinical trial: oral vs. intravenous iron after upper gastrointestinal haemorrhage-a placebo-controlled study. Aliment Pharmacol Ther. 2014;39(2):176-187. doi:10.1111/apt.12556

46. Bailie GR, Mason NA, Valaoras TG. Safety and tolerability of intravenous ferric carboxymaltose in patients with iron deficiency anemia. Hemodial Int. 2010;14(1):47-54. doi:10.1111/j.1542-4758.2009.00409.x

47. Barish CF, Koch $T$, Butcher $A$, Morris D, Bregman DB. Safety and efficacy of intravenous ferric carboxymaltose (750 mg) in the treatment of iron deficiency anemia: two randomized, controlled trials. Anemia. 2012;2012: 172104. doi:10.1155/2012/172104

48. Bastit $L$, Vandebroek A, Altintas $S$, et al. Randomized, multicenter, controlled trial comparing the efficacy and safety of darbepoetin alpha administered every 3 weeks with or without intravenous iron in patients with chemotherapy-induced anemia. J Clin Oncol. 2008;26(10):1611-1618. doi:10.1200/JCO.2006.10.4620

49. Batool S, Hahsmi KS, Janjua M. Comparison of the efficacy of IV iron versus oral iron therapy in postpartum anemia. Medical Forum Monthly. 2018;29(5):67-70.

50. Bayoumeu F, Subiran-Buisset C, Baka NE, Legagneur H, Monnier-Barbarino P, Laxenaire MC. Iron therapy in iron deficiency anemia in pregnancy: intravenous route versus oral route. Am J Obstet Gynecol. 2002;186(3) 518-522. doi:10.1067/mob.2002.121894

51. Beck-da-Silva L, Piardi D, Soder S, et al. IRON-HF study: a randomized trial to assess the effects of iron in heart failure patients with anemia. Int J Cardiol. 2013;168(4):3439-3442. doi:10.1016/j.ijcard.2013.04.181

52. Beguin $Y$, Maertens J, De Prijck $B$, et al. Darbepoetin-alfa and intravenous iron administration after autologous hematopoietic stem cell transplantation: a prospective multicenter randomized trial. Am J Hematol. 2013;88(12) 990-996. doi:10.1002/ajh.23552

53. Bencaiova G, von Mandach U, Zimmermann R. Iron prophylaxis in pregnancy: intravenous route versus oral route. Eur J Obstet Gynecol Reprod Biol. 2009;144(2):135-139. doi:10.1016/j.ejogrb.2009.03.006

54. Bernabeu-Wittel $M$, Romero $M$, Ollero-Baturone $M$, et al; PAHFRAC-01 Investigators. Ferric carboxymaltose with or without erythropoietin in anemic patients with hip fracture: a randomized clinical trial. Transfusion. 2016; 56(9):2199-2211. doi:10.1111/trf.13624

55. Bhandal N, Russell R. Intravenous versus oral iron therapy for postpartum anaemia. BJOG. 2006;113(11): 1248-1252. doi:10.1111/j.1471-0528.2006.01062.x

56. Bhavi SB, Jaju PB. Intravenous iron sucrose $\mathrm{v} / \mathrm{s}$ oral ferrous fumarate for treatment of anemia in pregnancy. a randomized controlled trial. BMC Pregnancy Childbirth. 2017;17(1):137. doi:10.1186/s12884-017-1313-9

57. Biboulet $P$, Bringuier $S$, Smilevitch $P$, et al. Preoperative epoetin-a with intravenous or oral iron for major orthopedic surgery: a randomized controlled trial. Anesthesiology. 2018;129(4):710-720. doi:10.1097/ALN. 0000000000002376 
58. Bielza R, Llorente J, Thuissard IJ, et al. Effect of intravenous iron on functional outcomes in hip fracture: a randomised controlled trial. Age Ageing. 2021;50(1):127-134. doi:10.1093/ageing/afaa107

59. Birgegård G, Henry D, Glaspy J, Chopra R, Thomsen LL, Auerbach M. A randomized noninferiority trial of intravenous iron isomaltoside versus oral iron sulfate in patients with nonmyeloid malignancies and anemia receiving chemotherapy: the PROFOUND trial. Pharmacotherapy. 2016;36(4):402-414. doi:10.1002/phar.1729

60. Birgegård G, Schneider K, Ulfberg J. High incidence of iron depletion and restless leg syndrome (RLS) in regular blood donors: intravenous iron sucrose substitution more effective than oral iron. Vox Sang. 2010;99(4): 354-361. doi:10.1111/j.1423-0410.2010.01368.x

61. Bisbe E, Moltó L, Arroyo R, Muniesa JM, Tejero M. Randomized trial comparing ferric carboxymaltose vs oral ferrous glycine sulphate for postoperative anaemia after total knee arthroplasty. Br J Anaesth. 2014;113(3): 402-409. doi:10.1093/bja/aeu092

62. Boomershine CS, Koch TA, Morris D. A blinded, randomized, placebo-controlled study to investigate the efficacy and safety of ferric carboxymaltose in iron-deficient patients with fibromyalgia. Rheumatol Ther. 2018;5 (1):271-281. doi:10.1007/s40744-017-0088-9

63. Breymann C, Gliga F, Bejenariu C, Strizhova N. Comparative efficacy and safety of intravenous ferric carboxymaltose in the treatment of postpartum iron deficiency anemia. Int J Gynaecol Obstet. 2008;101(1):67-73. doi:10.1016/j.ijgo.2007.10.009

64. Breymann C, Milman N, Mezzacasa A, Bernard R, Dudenhausen J; FER-ASAP investigators. Ferric carboxymaltose vs. oral iron in the treatment of pregnant women with iron deficiency anemia: an international, open-label, randomized controlled trial (FER-ASAP). J Perinat Med. 2017;45(4):443-453. doi:10.1515/.jpm2016-0050

65. Burden RJ, Pollock N, Whyte GP, et al. Effect of intravenous iron on aerobic capacity and iron metabolism in elite athletes. Med Sci Sports Exerc. 2015;47(7):1399-1407. doi:10.1249/MSS.0000000000000568

66. Burns DL, Mascioli EA, Bistrian BR. Effect of iron-supplemented total parenteral nutrition in patients with iron deficiency anemia. Nutrition. 1996;12(6):411-415. doi:10.1016/S0899-9007(96)00095-0

67. Charles-Edwards G, Amaral N, Sleigh A, et al. Effect of iron isomaltoside on skeletal muscle energetics in patients with chronic heart failure and iron deficiency. Circulation. 2019;139(21):2386-2398. doi:10.1161/ CIRCULATIONAHA.118.038516

68. Charytan C, Bernardo MV, Koch TA, Butcher A, Morris D, Bregman DB. Intravenous ferric carboxymaltose versus standard medical care in the treatment of iron deficiency anemia in patients with chronic kidney disease: a randomized, active-controlled, multi-center study. Nephrol Dial Transplant. 2013;28(4):953-964. doi:10.1093/ ndt/gfs528

69. Charytan C, Qunibi W, Bailie GR; Venofer Clinical Studies Group. Comparison of intravenous iron sucrose to oral iron in the treatment of anemic patients with chronic kidney disease not on dialysis. Nephron Clin Pract. 2005;100(3):c55-c62. doi:10.1159/000085049

70. Cho YW, Allen RP, Earley CJ. Clinical efficacy of ferric carboxymaltose treatment in patients with restless legs syndrome. Sleep Med. 2016;25:16-23. doi:10.1016/j.sleep.2016.06.021

71. Cho YW, Allen RP, Earley CJ. Efficacy of ferric carboxymaltose (FCM) $500 \mathrm{mg}$ dose for the treatment of restless legs syndrome. Sleep Med. 2018:42:7-12. doi:10.1016/j.sleep.2017.11.1134

72. Coyne DW, Kapoian T, Suki W, et al; DRIVE Study Group. Ferric gluconate is highly efficacious in anemic hemodialysis patients with high serum ferritin and low transferrin saturation: results of the Dialysis Patients' Response to IV Iron with Elevated Ferritin (DRIVE) Study. J Am Soc Nephrol. 2007;18(3):975-984. doi:10.1681/ ASN.2006091034

73. Dalal M, Goyal R, Nanda S, Dahiya P, Dahiya K, Madan S. Oral versus intravenous iron for treatment of iron deficiency anaemia in pregnancy: a randomized controlled trial. Indian J Public Health Res Dev. 2018;9(6):1-6. doi:10 5958/0976-5506.2018.00513.2

74. Damineni SC, Thunga S. IV ferric carboxymaltose vs oral iron in the treatment of post-partum iron deficiency anaemia. J Clin Diagn Res. 2016;10(11):QC08-QC10. doi:10.7860/JCDR/2016/19375.8937

75. Dangsuwan $P$, Manchana T. Blood transfusion reduction with intravenous iron in gynecologic cancer patients receiving chemotherapy. Gynecol Oncol. 2010;116(3):522-525. doi:10.1016/j.ygyno.2009.12.004

76. Darwish AM, Khalifa EE, Rashad E, Farghally E. Total dose iron dextran infusion versus oral iron for treating iron deficiency anemia in pregnant women: a randomized controlled trial. J Matern Fetal Neonatal Med. 2019;32(3): 398-403. doi:10.1080/14767058.2017.1379988

77. Deng Y, Wu J, Jia Q. Efficacy of intravenous iron sucrose in hemodialysis patients with restless legs syndrome (RLS): a randomized, placebo-controlled study. Med Sci Monit. 2017;23:1254-1260. doi:10.12659/MSM.900520 
78. Drexler $C$, Macher S, Lindenau I, et al. High-dose intravenous versus oral iron in blood donors with iron deficiency: the IronWoMan randomized, controlled clinical trial. Clin Nutr. 2020;39(3):737-745. doi:10.1016/j.clnu. 2019.03.025

79. Dubey S, Suri V, Aggarawal N, Das R. Is it safe to use intravenous iron sucrose during pregnancy? a randomized controlled trial. Int J Reprod Contracept Obstet Gynecol. 2013;2(4):544-549. doi:10.5455/2320-1770. ijrcog20131211

80. Edwards TJ, Noble EJ, Durran A, Mellor N, Hosie KB. Randomized clinical trial of preoperative intravenous iron sucrose to reduce blood transfusion in anaemic patients after colorectal cancer surgery. Br J Surg. 2009;96(10): 1122-1128. doi:10.1002/bjs.6688

81. El Khouly NI. Comparison of intravenous ferrous sucrose and oral ferrous sulphate in treatment of postpartum iron deficiency anemia. J Matern Fetal Neonatal Med. 2017;30(8):967-971. doi:10.1080/14767058.2016.1192602

82. Evstatiev R, Alexeeva O, Bokemeyer B, et al; FERGI Study Group. Ferric carboxymaltose prevents recurrence of anemia in patients with inflammatory bowel disease. Clin Gastroenterol Hepatol. 2013;11(3):269-277. doi:10.1016/j. cgh.2012.10.013

83. Shafi D, Purandare SV, Sathe AV. Iron deficiency anemia in pregnancy: intravenous versus oral route. J Obstet Gynaecol India. 2012;62(3):317-321. doi:10.1007/s13224-012-0222-0

84. Favrat $B, B a l c k K$, Breymann $C$, et al. Evaluation of a single dose of ferric carboxymaltose in fatigued, irondeficient women-PREFER a randomized, placebo-controlled study. PLoS One. 2014;9(4):e94217. doi:10.1371/ journal.pone.0094217

85. Ferrer-Barceló L, Sanchis Artero L, Sempere García-Argüelles J, et al. Randomised clinical trial: intravenous vs oral iron for the treatment of anaemia after acute gastrointestinal bleeding. Aliment Pharmacol Ther. 2019;50(3): 258-268. doi:10.1111/apt.15327

86. Fishbane S, Lynn RI. The efficacy of iron dextran for the treatment of iron deficiency in hemodialysis patients. Clin Nephrol. 1995:44(4):238-240.

87. Friel JK, Andrews WL, Hall MS, et al. Intravenous iron administration to very-low-birth-weight newborns receiving total and partial parenteral nutrition. JPEN J Parenter Enteral Nutr. 1995;19(2):114-118. doi:10.1177/ 0148607195019002114

88. Froessler B, Cocchiaro C, Saadat-Gilani K, Hodyl N, Dekker G. Intravenous iron sucrose versus oral iron ferrous sulfate for antenatal and postpartum iron deficiency anemia: a randomized trial. J Matern Fetal Neonatal Med. 2013;26(7):654-659. doi:10.3109/14767058.2012.746299

89. Froessler B, Palm P, Weber I, Hodyl NA, Singh R, Murphy EM. The important role for intravenous iron in perioperative patient blood management in major abdominal surgery: a randomized controlled trial. Ann Surg. 2016:264(1):41-46. doi:10.1097/SLA.0000000000001646

90. Garrido-Martín P, Nassar-Mansur MI, de la Llana-Ducrós R, et al. The effect of intravenous and oral iron administration on perioperative anaemia and transfusion requirements in patients undergoing elective cardiac surgery: a randomized clinical trial. Interact Cardiovasc Thorac Surg. 2012;15(6):1013-1018. doi:10.1093/icvts/ ivs344

91. Grote L, Leissner L, Hedner, J, Ulfberg J. A randomized double-blind, placebo controlled, multi-center study of intravenous iron sucrose and placebo in the treatment of restless leg syndrome. Mov Disord. 2009;24(10):14451452.

92. Gupta A, Manaktala U, Rathore AM. A randomised controlled trial to compare intravenous iron sucrose and oral iron in treatment of iron deficiency anemia in pregnancy. Indian J Hematol Blood Transfus. 2014;30(2): 120-125. doi:10.1007/s12288-012-0224-1

93. Hedenus $M$, Birgegård $G$, Näsman $P$, et al. Addition of intravenous iron to epoetin beta increases hemoglobin response and decreases epoetin dose requirement in anemic patients with lymphoproliferative malignancies: a randomized multicenter study. Leukemia. 2007;21(4):627-632. doi:10.1038/sj.leu.2404562

94. Hedenus $M$, Karlsson $T$, Ludwig $H$, et al. Intravenous iron alone resolves anemia in patients with functional iron deficiency and lymphoid malignancies undergoing chemotherapy. Med Oncol. 2014;31(12):302. doi:10.1007/ s12032-014-0302-3

95. Henry DH, Dahl NV, Auerbach M, Tchekmedyian S, Laufman LR. Intravenous ferric gluconate significantly improves response to epoetin alfa versus oral iron or no iron in anemic patients with cancer receiving chemotherapy. Oncologist. 2007;12(2):231-242. doi:10.1634/theoncologist.12-2-231

96. Holm C, Thomsen LL, Norgaard A, Langhoff-Roos J. Single-dose intravenous iron infusion or oral iron for treatment of fatigue after postpartum haemorrhage: a randomized controlled trial. Vox Sang. 2017;112(3):219-228. doi:10.1111/vox.12477 
97. lyoke CA, Emegoakor FC, Ezugwu EC, et al. Effect of treatment with single total-dose intravenous iron versus daily oral iron(III)-hydroxide polymaltose on moderate puerperal iron-deficiency anemia. Ther Clin Risk Manag. 2017;13:647-653. doi:10.2147/TCRM.S112227

98. Jain G, Palaria U, Jha SK. Intravenous iron in postpartum anemia. J Obstet Gynaecol India. 2013;63(1):45-48. doi:10.1007/s13224-012-0240-y

99. Johansson PI, Rasmussen AS, Thomsen LL. Intravenous iron isomaltoside 1000 (Monofer ${ }^{\circledR}$ ) reduces postoperative anaemia in preoperatively non-anaemic patients undergoing elective or subacute coronary artery bypass graft, valve replacement or a combination thereof: a randomized double-blind placebo-controlled clinical trial (the PROTECT trial). Vox Sang. 2015;109(3):257-266. doi:10.1111/vox.12278

100. Kalra PA, Bhandari S, Saxena S, et al. A randomized trial of iron isomaltoside 1000 versus oral iron in non-dialysis-dependent chronic kidney disease patients with anaemia. Nephrol Dial Transplant. 2016;31(4): 646-655. doi:10.1093/ndt/gfv293

101. Karkouti K, McCluskey SA, Ghannam M, Salpeter MJ, Quirt I, Yau TM. Intravenous iron and recombinant erythropoietin for the treatment of postoperative anemia. Can J Anaesth. 2006;53(1):11-19. doi:10.1007/ BF03021522

102. Kasper SM, Lazansky H, Stark C, Klimek M, Laubinger R, Börner U. Efficacy of oral iron supplementation is not enhanced by additional intravenous iron during autologous blood donation. Transfusion. 1998;38(8):764-770. doi:10.1046/j.1537-2995.1998.38898375516.x

103. Keeler BD, Simpson JA, Ng O, Padmanabhan H, Brookes MJ, Acheson AG; IVICA Trial Group. Randomized clinical trial of preoperative oral versus intravenous iron in anaemic patients with colorectal cancer. Br J Surg. 2017; 104(3):214-221. doi:10.1002/bjs.10328

104. Keller $P$, von Känel $R$, Hincapié $C A$, et al. The effects of intravenous iron supplementation on fatigue and general health in non-anemic blood donors with iron deficiency: a randomized placebo-controlled superiority trial. Sci Rep. 2020;10(1):14219. doi:10.1038/s41598-020-71048-0

105. Khalafallah A, Dennis A, Bates J, et al. A prospective randomized, controlled trial of intravenous versus oral iron for moderate iron deficiency anaemia of pregnancy. J Intern Med. 2010;268(3):286-295. doi:10.1111/j.13652796.2010.02251.x

106. Khalafallah AA, Hyppa A, Chuang A, et al. A prospective randomised controlled trial of a single intravenous infusion of ferric carboxymaltose vs single intravenous iron polymaltose or daily oral ferrous sulphate in the treatment of iron deficiency anaemia in pregnancy. Semin Hematol. 2018;55(4):223-234. doi:10.1053/j. seminhematol.2018.04.006

107. Khalafallah AA, Yan C, Al-Badri R, et al. Intravenous ferric carboxymaltose versus standard care in the management of postoperative anaemia: a prospective, open-label, randomised controlled trial. Lancet Haematol. 2016;3(9):e415-e425. doi:10.1016/\$2352-3026(16)30078-3

108. Litton E, Baker S, Erber WN, et al; IRONMAN Investigators; Australian and New Zealand Intensive Care Society Clinical Trials Group. Intravenous iron or placebo for anaemia in intensive care: the IRONMAN multicentre randomized blinded trial: a randomized trial of IV iron in critical illness. Intensive Care Med. 2016;42(11): 1715-1722. doi:10.1007/s00134-016-4465-6

109. Kim YH, Chung HH, Kang SB, Kim SC, Kim YT. Safety and usefulness of intravenous iron sucrose in the management of preoperative anemia in patients with menorrhagia: a phase IV, open-label, prospective, randomized study. Acta Haematol. 2009;121(1):37-41. doi:10.1159/000210062

110. Kim YT, Kim SW, Yoon BS, et al. Effect of intravenously administered iron sucrose on the prevention of anemia in the cervical cancer patients treated with concurrent chemoradiotherapy. Gynecol Oncol. 2007;105(1):199-204. doi:10.1016/j.ygyno.2006.11.014

111. Kim YW, Bae JM, Park YK, et al; FAIRY Study Group. Effect of intravenous ferric carboxymaltose on hemoglobin response among patients with acute isovolemic anemia following gastrectomy: the FAIRY Randomized Clinical Trial. JAMA. 2017;317(20):2097-2104. doi:10.1001/jama.2017.5703

112. Kochhar PK, Kaundal A, Ghosh P. Intravenous iron sucrose versus oral iron in treatment of iron deficiency anemia in pregnancy: a randomized clinical trial. J Obstet Gynaecol Res. 2013;39(2):504-510. doi:10.1111/j.14470756.2012.01982.x

113. KrayenbuehI PA, Battegay E, Breymann C, Furrer J, Schulthess G. Intravenous iron for the treatment of fatigue in nonanemic, premenopausal women with low serum ferritin concentration. Blood. 2011;118(12):3222-3227. doi: 10.1182/blood-2011-04-346304 
114. Kulnigg $S$, Stoinov $S$, Simanenkov $V$, et al. A novel intravenous iron formulation for treatment of anemia in inflammatory bowel disease: the ferric carboxymaltose (FERINJECT) randomized controlled trial. Am J Gastroenterol. 2008;103(5):1182-1192. doi:10.1111/j.1572-0241.2007.01744.x

115. Kulnigg-Dabsch S, Schmid W, Howaldt S, et al. Iron deficiency generates secondary thrombocytosis and platelet activation in IBD: the randomized, controlled thromboVIT trial. Inflamm Bowel Dis. 2013;19(8):1609-1616. doi:10.1097/MIB.0b013e318281f4db

116. Kuo KL, Hung SC, Wei YH, Tarng DC. Intravenous iron exacerbates oxidative DNA damage in peripheral blood lymphocytes in chronic hemodialysis patients. J Am Soc Nephrol. 2008;19(9):1817-1826. doi:10.1681/ASN. 2007101084

117. Li H, Wang SX. Intravenous iron sucrose in peritoneal dialysis patients with renal anemia. Perit Dial Int. 2008; 28(2):149-154. doi:10.1177/089686080802800210

118. Lindgren S, Wikman $O$, Befrits R, et al. Intravenous iron sucrose is superior to oral iron sulphate for correcting anaemia and restoring iron stores in IBD patients: a randomized, controlled, evaluator-blind, multicentre study. Scand J Gastroenterol. 2009;44(7):838-845. doi:10.1080/00365520902839667

119. Macciò A, Madeddu C, Gramignano G, Mulas C, Sanna E, Mantovani G. Efficacy and safety of oral lactoferrin supplementation in combination with rHuEPO-beta for the treatment of anemia in advanced cancer patients undergoing chemotherapy: open-label, randomized controlled study. Oncologist. 2010;15(8):894-902. doi:10. 1634/theoncologist.2010-0020

120. MacDougall IC, Bock AH, Carrera F, et al; FIND-CKD Study Investigators. FIND-CKD: a randomized trial of intravenous ferric carboxymaltose versus oral iron in patients with chronic kidney disease and iron deficiency anaemia. Nephrol Dial Transplant. 2014;29(11):2075-2084. doi:10.1093/ndt/gfu201

121. MacDougall IC, Tucker B, Thompson J, Tomson CR, Baker LR, Raine AE. A randomized controlled study of iron supplementation in patients treated with erythropoietin. Kidney Int. 1996;50(5):1694-1699. doi:10.1038/ki. 1996.487

122. Madi-Jebara SN, Sleilaty GS, Achouh PE, et al. Postoperative intravenous iron used alone or in combination with low-dose erythropoietin is not effective for correction of anemia after cardiac surgery. J Cardiothorac Vasc Anesth. 2004;18(1):59-63. doi:10.1053/j.jvca.2003.10.012

123. McMahon $L P$, Kent $A B$, Kerr PG, et al. Maintenance of elevated versus physiological iron indices in non-anaemic patients with chronic kidney disease: a randomized controlled trial. Nephrol Dial Transplant. 2010;25 (3):920-926. doi:10.1093/ndt/gfp584

124. Meyer MP, Haworth C, Meyer JH, Commerford A. A comparison of oral and intravenous iron supplementation in preterm infants receiving recombinant erythropoietin. J Pediatr. 1996;129(2):258-263. doi:10.1016/S00223476(96)70251-2

125. Michael B, Coyne DW, Fishbane S, et al; Ferrlecit Publication Committee. Sodium ferric gluconate complex in hemodialysis patients: adverse reactions compared to placebo and iron dextran. Kidney Int. 2002;61(5):

1830-1839. doi:10.1046/j.1523-1755.2002.00314.x

126. Montano-Pedroso JC, Bueno Garcia E, Alcântara Rodrigues de Moraes M, Francescato Veiga D, Masako Ferreira L. Intravenous iron sucrose versus oral iron administration for the postoperative treatment of postbariatric abdominoplasty anaemia: an open-label, randomised, superiority trial in Brazil. Lancet Haematol. 2018;5 (7):e310-e320. doi:10.1016/S2352-3026(18)30071-1

127. Moppett IK, Rowlands M, Mannings AM, Marufu TC, Sahota O, Yeung J. The effect of intravenous iron on erythropoiesis in older people with hip fracture. Age Ageing. 2019;48(5):751-755. doi:10.1093/ageing/afz049

128. Mudge DW, Tan KS, Miles R, et al. A randomized controlled trial of intravenous or oral iron for posttransplant anemia in kidney transplantation. Transplantation. 2012;93(8):822-826. doi:10.1097/TP.0b013e318248375a

129. Na HS, Shin SY, Hwang JY, Jeon YT, Kim CS, Do SH. Effects of intravenous iron combined with low-dose recombinant human erythropoietin on transfusion requirements in iron-deficient patients undergoing bilateral total knee replacement arthroplasty. Transfusion. 2011;51(1):118-124. doi:10.1111/j.1537-2995.2010.02783.x

130. Nanthini R, Mamatha R, Shivmurthy G, Kavitha K. A comparative prospective study to assess the efficacy and safety of iron sucrose versus iron sorbitol citric acid in pregnant women with iron deficiency anemia in a tertiary care hospital. Natl J Physiol Pharm Pharmacol. 2017;7:545-551.

131. Neeru S, Nair NS, Rai L. Iron sucrose versus oral iron therapy in pregnancy anemia. Indian J Community Med. 2012;37(4):214-218. doi:10.4103/0970-0218.103467 
132. Neogi SB, Devasenapathy N, Singh R, et al. Safety and effectiveness of intravenous iron sucrose versus standard oral iron therapy in pregnant women with moderate-to-severe anaemia in India: a multicentre, openlabel, phase 3, randomised, controlled trial. Lancet Glob Health. 2019;7(12):e1706-e1716. doi:10.1016/S2214-109X (19)30427-9

133. Ng O, Keeler B, Simpson JA, Madhusudan S, Brookes M, Acheson A. Feasibility of intravenous iron isomaltoside to improve anemia and quality of life during palliative chemotherapy for esophagogastric adenocarcinoma. Nutr Cancer. 2018;70(7):1106-1117. doi:10.1080/01635581.2018.1504090

134. Noronha V, Joshi A, Patil VM, et al. Phase III randomized trial comparing intravenous to oral iron in patients with cancer-related iron deficiency anemia not on erythropoiesis stimulating agents. Asia Pac J Clin Oncol. 2018;14 (2):e129-e137. doi:10.1111/ajco.12762

135. Okonko DO, Grzeslo A, Witkowski T, et al. Effect of intravenous iron sucrose on exercise tolerance in anemic and nonanemic patients with symptomatic chronic heart failure and iron deficiency FERRIC-HF: a randomized, controlled, observer-blinded trial. J Am Coll Cardiol. 2008;51(2):103-112. doi:10.1016/j.jacc.2007.09.036

136. Olijhoek G, Megens JG, Musto P, et al. Role of oral versus IV iron supplementation in the erythropoietic response to rHuEPO: a randomized, placebo-controlled trial. Transfusion. 2001;41(7):957-963. doi:10.1046/j.15372995.2001.41070957.x

137. Onken JE, Bregman DB, Harrington RA, et al. A multicenter, randomized, active-controlled study to investigate the efficacy and safety of intravenous ferric carboxymaltose in patients with iron deficiency anemia. Transfusion. 2014;54(2):306-315.

138. Padmanabhan $\mathrm{H}$, Siau K, Nevill AM, et al. Intravenous iron does not effectively correct preoperative anaemia in cardiac surgery: a pilot randomized controlled trial. Interact Cardiovasc Thorac Surg. 2019;28(3):447-454. doi: 10.1093/icvts/ivy226

139. Park HS, Kim TY, Kim HJ, Ro YJ, Jang HY, Koh WU. The effect of intraoperative ferric carboxymaltose in joint arthroplasty patients: a randomized trial. J Clin Med. 2019;8(10):13. doi:10.3390/jcm8101674

140. Pedrazzoli P, Farris A, Del Prete $S$, et al. Randomized trial of intravenous iron supplementation in patients with chemotherapy-related anemia without iron deficiency treated with darbepoetin alpha. J Clin Oncol. 2008;26 (10):1619-1625. doi:10.1200/JCO.2007.12.2051

141. Perelló MF, Coloma JL, Masoller N, Esteve J, Palacio M. Intravenous ferrous sucrose versus placebo in addition to oral iron therapy for the treatment of severe postpartum anaemia: a randomised controlled trial. BJOG. 2014; 121(6):706-713. doi:10.1111/1471-0528.12480

142. Pieracci FM, Stovall RT, Jaouen B, et al. A multicenter, randomized clinical trial of IV iron supplementation for anemia of traumatic critical illness. Crit Care Med. 2014;42(9):2048-2057. doi:10.1097/CCM. 0000000000000408

143. Pollak A, Hayde M, Hayn M, et al. Effect of intravenous iron supplementation on erythropoiesis in erythropoietin-treated premature infants. Pediatrics. 2001;107(1):78-85. doi:10.1542/peds.107.1.78

144. Ponikowski P, Kirwan BA, Anker SD, et al; AFFIRM-AHF investigators. Ferric carboxymaltose for iron deficiency at discharge after acute heart failure: a multicentre, double-blind, randomised, controlled trial. Lancet. 2020;396(10266):1895-1904. doi:10.1016/50140-6736(20)32339-4

145. Ponikowski P, van Veldhuisen DJ, Comin-Colet J, et al; CONFIRM-HF Investigators. Beneficial effects of longterm intravenous iron therapy with ferric carboxymaltose in patients with symptomatic heart failure and iron deficiency. Eur Heart J. 2015;36(11):657-668. doi:10.1093/eurheartj/ehu385

146. Price $E$, Artz AS, Barnhart $H$, et al. A prospective randomized wait list control trial of intravenous iron sucrose in older adults with unexplained anemia and serum ferritin 20-200 ng/mL. Blood Cells Mol Dis. 2014;53(4): 221-230. doi:10.1016/j.bcmd.2014.06.003

147. Provenzano R, Schiller B, Rao M, Coyne D, Brenner L, Pereira BJ. Ferumoxytol as an intravenous iron replacement therapy in hemodialysis patients. Clin J Am Soc Nephrol. 2009;4(2):386-393. doi:10.2215/CJN. 02840608

148. Qunibi WY, Martinez C, Smith M, Benjamin J, Mangione A, Roger SD. A randomized controlled trial comparing intravenous ferric carboxymaltose with oral iron for treatment of iron deficiency anaemia of non-dialysisdependent chronic kidney disease patients. Nephrol Dial Transplant. 2011;26(5):1599-1607. doi:10.1093/ndt/ gfq613

149. Rathod S, Samal SK, Mahapatra PC, Samal S. Ferric carboxymaltose: a revolution in the treatment of postpartum anemia in Indian women. Int J Appl Basic Med Res. 2015;5(1):25-30. doi:10.4103/2229-516X.149230 
150. Reinisch W, Staun M, Tandon RK, et al. A randomized, open-label, non-inferiority study of intravenous iron isomaltoside 1,000 (Monofer) compared with oral iron for treatment of anemia in IBD (PROCEED). Am J Gastroenterol. 2013;108(12):1877-1888. doi:10.1038/ajg.2013.335

151. Richards T, Baikady RR, Clevenger B, et al. Preoperative intravenous iron to treat anaemia before major abdominal surgery (PREVENTT): a randomised, double-blind, controlled trial. Lancet. 2020;396(10259): 1353-1361. doi:10.1016/S0140-6736(20)31539-7

152. Rudra S, Chandna A, Nath J. Comparison of intravenous iron sucrose with oral iron in pregnant women with iron deficiency anaemia. Int J Reprod Contracept Obstet Gynecol. 2016;5(3):747-751. doi:10.18203/2320-1770. ijrcog20160577

153. Santer $P$, McGahey A, Frise MC, et al. Intravenous iron and chronic obstructive pulmonary disease: a randomised controlled trial. BMJ Open Respir Res. 2020;7(1):6. doi:10.1136/bmjresp-2020-000577

154. Schijns W, Boerboom A, de Bruyn Kops M, et al. A randomized controlled trial comparing oral and intravenous iron supplementation after Roux-en-Y gastric bypass surgery. Clin Nutr. 2020;39(12):3779-3785. doi:10.1016/j. clnu.2020.04.010

155. Schröder $O$, Mickisch $O$, Seidler $U$, et al. Intravenous iron sucrose versus oral iron supplementation for the treatment of iron deficiency anemia in patients with inflammatory bowel disease-a randomized, controlled, openlabel, multicenter study. Am J Gastroenterol. 2005;100(11):2503-2509. doi:10.1111/j.1572-0241.2005.00250.x

156. Sedighi O, Makhlough A, Janbabai G, Neemi M. Comparative study of intravenous iron versus intravenous ascorbic acid for treatment of functional iron deficiency in patients under hemodialysis: a randomized clinical trial. Nephrourol Mon. 2013;5(4):913-917. doi:10.5812/numonthly.12038

157. Seid MH, Butcher AD, Chatwani A. Ferric carboxymaltose as treatment in women with iron-deficiency anemia. Anemia. 2017;2017:9642027. doi:10.1155/2017/9642027

158. Seid MH, Derman RJ, Baker JB, Banach W, Goldberg C, Rogers R. Ferric carboxymaltose injection in the treatment of postpartum iron deficiency anemia: a randomized controlled clinical trial. Am J Obstet Gynecol. 2008; 199(4):435, e431-e437. doi:10.1016/j.ajog.2008.07.046

159. Serrano-Trenas JA, Ugalde PF, Cabello LM, Chofles LC, Lázaro PS, Benítez PC. Role of perioperative intravenous iron therapy in elderly hip fracture patients: a single-center randomized controlled trial. Transfusion. 2011;51(1):97-104. doi:10.1111/j.1537-2995.2010.02769.x

160. Singh H, Reed J, Noble S, Cangiano JL, Van Wyck DB; United States Iron Sucrose (Venofer) Clinical Trials Group. Effect of intravenous iron sucrose in peritoneal dialysis patients who receive erythropoiesis-stimulating agents for anemia: a randomized, controlled trial. Clin J Am Soc Nephrol. 2006;1(3):475-482. doi:10.2215/CJN. 01541005

161. Singh $K$, Fong YF, Kuperan P. A comparison between intravenous iron polymaltose complex (Ferrum Hausmann) and oral ferrous fumarate in the treatment of iron deficiency anaemia in pregnancy. Eur $\mathrm{J}$ Haematol. 1998;60(2):119-124. doi:10.1111/j.1600-0609.1998.tb01008.x

162. Sloand JA, Shelly MA, Feigin A, Bernstein P, Monk RD. A double-blind, placebo-controlled trial of intravenous iron dextran therapy in patients with ESRD and restless legs syndrome. Am J Kidney Dis. 2004;43(4):663-670. doi:10.1053/j.ajkd.2003.11.021

163. Spahn DR, Schoenrath F, Spahn GH, et al. Effect of ultra-short-term treatment of patients with iron deficiency or anaemia undergoing cardiac surgery: a prospective randomised trial. Lancet. 2019;393(10187):2201-2212. doi: 10.1016/S0140-6736(18)32555-8

164. Spinowitz BS, Kausz AT, Baptista J, et al. Ferumoxytol for treating iron deficiency anemia in CKD. J Am Soc Nephrol. 2008;19(8):1599-1605. doi:10.1681/ASN.2007101156

165. Steensma DP, Sloan JA, Dakhil SR, et al. Phase III, randomized study of the effects of parenteral iron, oral iron, or no iron supplementation on the erythropoietic response to darbepoetin alfa for patients with chemotherapyassociated anemia. J Clin Oncol. 2011;29(1):97-105. doi:10.1200/JCO.2010.30.3644

166. Stoves J, Inglis H, Newstead CG. A randomized study of oral vs intravenous iron supplementation in patients with progressive renal insufficiency treated with erythropoietin. Nephrol Dial Transplant. 2001;16(5):967-74.

167. Toblli JE, Lombraña A, Duarte P, Di Gennaro F. Intravenous iron reduces NT-pro-brain natriuretic peptide in anemic patients with chronic heart failure and renal insufficiency. J Am Coll Cardiol. 2007;50(17):1657-1665. doi: 10.1016/j.jacc.2007.07.029

168. Trenkwalder C, Winkelmann J, Oertel W, Virgin G, Roubert B, Mezzacasa A; FCM-RLS Study Investigators. Ferric carboxymaltose in patients with restless legs syndrome and nonanemic iron deficiency: a randomized trial. Mov Disord. 2017;32(10):1478-1482. doi:10.1002/mds.27040 
169. Razzaq M, Azam MI, Naeem MF. Comparison between intravenous iron and oral iron therapy in cases of postpartum anemia. Pakistan Journal of Medical and Health Sciences. 2017; 11(1):277-280.

170. Vadhan-Raj S, Strauss W, Ford D, et al. Efficacy and safety of IV ferumoxytol for adults with iron deficiency anemia previously unresponsive to or unable to tolerate oral iron. Am J Hematol. 2014;89(1):7-12. doi:10.1002/ ajh.23582

171. van Iperen CE, Gaillard CA, Kraaijenhagen RJ, Braam BG, Marx JJ, van de Wiel A. Response of erythropoiesis and iron metabolism to recombinant human erythropoietin in intensive care unit patients. Crit Care Med. 2000; 28(8):2773-2778. doi:10.1097/00003246-200008000-00015

172. van Veldhuisen DJ, Ponikowski P, van der Meer P, et al; EFFECT-HF Investigators. Effect of ferric carboxymaltose on exercise capacity in patients with chronic heart failure and iron deficiency. Circulation. 2017; 136(15):1374-1383. doi:10.1161/CIRCULATIONAHA.117.027497

173. Van Wyck DB, Mangione A, Morrison J, Hadley PE, Jehle JA, Goodnough LT. Large-dose intravenous ferric carboxymaltose injection for iron deficiency anemia in heavy uterine bleeding: a randomized, controlled trial. Transfusion. 2009;49(12):2719-2728. doi:10.1111/j.1537-2995.2009.02327.x

174. Van Wyck DB, Martens MG, Seid MH, Baker JB, Mangione A. Intravenous ferric carboxymaltose compared with oral iron in the treatment of postpartum anemia: a randomized controlled trial. Obstet Gynecol. 2007;110(2 pt 1):267-278. doi:10.1097/01.AOG.0000275286.03283.18

175. Van Wyck DB, Roppolo M, Martinez CO, Mazey RM, McMurray S; United States Iron Sucrose (Venofer) Clinical Trials Group. A randomized, controlled trial comparing IV iron sucrose to oral iron in anemic patients with nondialysis-dependent CKD. Kidney Int. 2005;68(6):2846-2856. doi:10.1111/j.1523-1755.2005.00758.x

176. Vanobberghen $F$, Lweno $O$, Kuemmerle A, et al. Efficacy and safety of intravenous ferric carboxymaltose compared with oral iron for the treatment of iron deficiency anaemia in women after childbirth in Tanzania: a parallel-group, open-label, randomised controlled phase 3 trial. Lancet Global Health. 2021;9(2):e189-e198. doi: $10.1016 / 52214-109 \times(20) 30448-4$

177. Warady BA, Kausz A, Lerner G, et al. Iron therapy in the pediatric hemodialysis population. Pediatr Nephrol. 2004;19(6):655-661. doi:10.1007/s00467-004-1457-5

178. Weisbach V, Skoda P, Rippel R, et al. Oral or intravenous iron as an adjuvant to autologous blood donation in elective surgery: a randomized, controlled study. Transfusion. 1999;39(5):465-472. doi:10.1046/j.1537-2995.1999. 39050465.x

179. Westad S, Backe B, Salvesen KA, et al. A 12-week randomised study comparing intravenous iron sucrose versus oral ferrous sulphate for treatment of postpartum anemia. Acta Obstet Gynecol Scand. 2008;87(9): 916-923. doi:10.1080/00016340802317802

180. Woods A, Garvican-Lewis LA, Saunders PU, et al. Four weeks of IV iron supplementation reduces perceived fatigue and mood disturbance in distance runners. PLoS One. 2014;9(9):e108042. doi:10.1371/journal.pone. 0108042

181. Xu H, Duan Y, Yuan X, Wu H, Sun H, Ji H. Intravenous iron versus placebo in the management of postoperative functional iron deficiency anemia in patients undergoing cardiac valvular surgery: a prospective, single-blinded, randomized controlled trial. J Cardiothorac Vasc Anesth. 2019;33(11):2941-2948. doi:10.1053/j.jvca.2019.01.063

182. Yeo TJ, Yeo PSD, Hadi FA, et al. Single-dose intravenous iron in Southeast Asian heart failure patients: a pilot randomized placebo-controlled study (PRACTICE-ASIA-HF). ESC Heart Fail. 2018;5(2):344-353. doi:10.1002/ ehf2.12250

183. Yoo YC, Shim JK, Kim JC, Jo YY, Lee JH, Kwak YL. Effect of single recombinant human erythropoietin injection on transfusion requirements in preoperatively anemic patients undergoing valvular heart surgery. Anesthesiology. 2011;115(5):929-937. doi:10.1097/ALN.0b013e318232004b

184. Verma $S$, Inamdar $S A$, Malhotra N. Intravenous iron therapy versus oral iron in postpartum patients in rural are. Journal of South Asian Federation of Obstetrics and Gynaecology . 2011;3(2):67-70. doi:10.5005/jp-journals10006-1131

185. Ikuta K, Ito H, Takahashi K, Masaki S, Terauchi M, Suzuki Y. Safety and efficacy of intravenous ferric carboxymaltose in Japanese patients with iron-deficiency anemia caused by digestive diseases: an open-label, single-arm study. Int J Hematol. 2019;109(1):50-58. doi:10.1007/s12185-018-2529-9

186. Ishida JH, Marafino BJ, McCulloch CE, et al. Receipt of intravenous iron and clinical outcomes among hemodialysis patients hospitalized for infection. Clin J Am Soc Nephrol. 2015;10(10):1799-1805. doi:10.2215/CJN. 01090115

187. Kim SK, Seo WY, Kim HJ, Yoo JJ. Postoperative intravenous ferric carboxymaltose reduces transfusion amounts after orthopedic hip surgery. Clin Orthop Surg. 2018;10(1):20-25. doi:10.4055/cios.2018.10.1.20 
188. Kuragano $T$, Matsumura $O$, Matsuda $A$, et al. Association between hemoglobin variability, serum ferritin levels, and adverse events/mortality in maintenance hemodialysis patients. Kidney Int. 2014;86(4):845-854. doi: 10.1038/ki.2014.114

189. Muñoz M, Gómez-Ramírez S, Cuenca J, et al. Very-short-term perioperative intravenous iron administration and postoperative outcome in major orthopedic surgery: a pooled analysis of observational data from 2547 patients. Transfusion. 2014;54(2):289-299.

190. Peters F, Eveslage M, Gallitz I, et al. Post-operative iron carboxymaltose may have an effect on haemoglobin levels in cardiothoracic surgical patients on the ICU-an observational pilot study about anaemia treatment with intravenous iron. Transfus Med Hemother. 2018;45(1):42-46. doi:10.1159/000481143

191. Zitt E, Sturm G, Kronenberg F, et al. Iron supplementation and mortality in incident dialysis patients: an observational study. PLoS One. 2014;9(12):e114144. doi:10.1371/journal.pone.0114144

192. Muñoz M, Gómez-Ramírez S, Martín-Montañez E, Naveira E, Seara J, Pavía J. Cost of post-operative intravenous iron therapy in total lower limb arthroplasty: a retrospective, matched cohort study. Blood Transfus. 2014;12(1):40-49.

193. MedDRA Medical Dictionary for Regulatory Activities. Accessed September 28, 2021. http://www.meddramsso. com/index.asp

194. Bonovas S, Fiorino G, Allocca M, et al. Intravenous versus oral iron for the treatment of anemia in inflammatory bowel disease: a systematic review and meta-analysis of randomized controlled trials. Medicine (Baltimore). 2016;95(2):e2308. doi:10.1097/MD.0000000000002308

195. Suffredini DA, Xu W, Sun J, et al. Parenteral irons versus transfused red blood cells for treatment of anemia during canine experimental bacterial pneumonia. Transfusion. 2017;57(10):2338-2347. doi:10.1111/trf.14214

196. Deicher R, Ziai F, Cohen G, Müllner M, Hörl WH. High-dose parenteral iron sucrose depresses neutrophil intracellular killing capacity. Kidney Int. 2003;64(2):728-736. doi:10.1046/j.1523-1755.2003.00125.x

197. Frost JN, Tan TK, Abbas M, et al Hepcidin-mediated hypoferremia disrupts immune responses to vaccination and infection. Med N Y. 2021;2(2):164-179.e12. doi:10.1016/j.medj.2020.10.004

198. Reinisch W, Staun M, Bhandari S, Muñoz M. State of the iron: how to diagnose and efficiently treat iron deficiency anemia in inflammatory bowel disease. J Crohns Colitis. 2013;7(6):429-440. doi:10.1016/j.crohns.2012. 07.031

199. Viget N, Vernier-Massouille G, Salmon-Ceron D, Yazdanpanah Y, Colombel JF. Opportunistic infections in patients with inflammatory bowel disease: prevention and diagnosis. Gut. 2008;57(4):549-558. doi:10.1136/gut. 2006.114660

200. Garner JS, Jarvis WR, Emori TG, Horan TC, Hughes JM. CDC definitions for nosocomial infections, 1988. Am J Infect Control. 1988;16(3):128-140. doi:10.1016/0196-6553(88)90053-3

201. Dindo D, Demartines N, Clavien PA. Classification of surgical complications: a new proposal with evaluation in a cohort of 6336 patients and results of a survey. Ann Surg. 2004;240(2):205-213. doi:10.1097/01.sla. 0000133083.54934.ae

202. Singer M, Deutschman CS, Seymour CW, et al. The Third International Consensus Definitions for Sepsis and Septic Shock (Sepsis-3). JAMA. 2016;315(8):801-810. doi:10.1001/jama.2016.0287

203. Barnes J, Hunter J, Harris S, et al; StEP-COMPAC group. Systematic review and consensus definitions for the Standardised Endpoints in Perioperative Medicine (StEP) initiative: infection and sepsis. Br J Anaesth. 2019;122 (4):500-508. doi:10.1016/j.bja.2019.01.009

204. Swenson $E R$, Porcher $R$, Piagnerelli M. Iron deficiency and infection: another pathway to explore in critically ill patients? Intensive Care Med. 2018;44(12):2260-2262. doi:10.1007/s00134-018-5438-8

205. McDermid JM, Prentice AM. Iron and infection: effects of host iron status and the iron-regulatory genes haptoglobin and NRAMP1 (SLC11A1) on host-pathogen interactions in tuberculosis and HIV. Clin Sci (Lond). 2006; 110(5):503-524. doi:10.1042/CS20050273

206. Pasricha $S R$, Armitage $A E$, Prentice $A M$, Drakesmith $H$. Reducing anaemia in low income countries: control of infection is essential. BMJ. 2018;362:k3165. doi:10.1136/bmj.k3165

207. Macdougall IC, White C, Anker SD, et al; PIVOTAL Investigators and Committees. Intravenous iron in patients undergoing maintenance hemodialysis. N Engl J Med. 2019;380(5):447-458. doi:10.1056/NEJMoa1810742

208. Strauss WE, Auerbach $M$. Health-related quality of life in patients with iron deficiency anemia: impact of treatment with intravenous iron. Patient Relat Outcome Meas. 2018;9:285-298. doi:10.2147/PROM.S169653 
SUPPLEMENT.

eAppendix 1. Search Strategy

eAppendix 2. Descriptive Summary of Findings of Included Nonrandomized Studies (NRS)

eAppendix 3. GRADE Assessment for Primary Outcome

eTable 1. Characteristics of Included RCTs

eTable 2. Characteristics of Ongoing RCTs

eTable 3. Characteristics of Included NRS

eTable 4. Summary of Risk of Bias Assessment for Nonrandomized Studies

eTable 5. Risk of Bias Assessments for Individual RCTs

eTable 6. Meta-regression Analyses

eTable 7. Summary of Reporting of Infection in Included Studies

eFigure 1. Risk of Bias Summary for RCTs

eFigure 2. Funnel Plot for Primary Outcome

eFigure 3. Sensitivity Analysis for Primary Outcome

eFigure 4. Subgroup analysis by clinical setting

eFigure 5. Subgroup Analysis by Type of Preparation, Dosing Schedule and Iron Profile at Enrollment on the Risk

of Infection

eFigure 6. Secondary Outcome-Hemoglobin Forest Plot

eFigure 7. Secondary Outcomes-Red Blood Cell (RBC) Transfusion Requirements

eFigure 8. Secondary Outcomes-Mortality and Length of Stay Forest Plots 